\title{
PENGARUH PARTISIPASI PENYUSUNAN ANGGARAN TERHADAP KINERJA MANAJERIAL DENGAN JOB RELEVANT INFORMATION SEBAGAI VARIABEL MODERATING
}

\author{
Usman Rahman \\ Email: usmanrahman@gmail.com \\ Universitas Muslim Indonesia Makassar \\ Basri modding \\ Email: usmanrahman@gmail.com \\ Universitas Muslim Indonesia Makassar \\ Amiruddin \\ Email: usmanrahman@gmail.com \\ Universitas Muslim Indonesia Makassar
}

\begin{abstract}
Abstrak
Penelitian ini bertujuan untuk mengetahui dan menguji secara empiris pengaruh partisipasi penyusunan anggaran terhadap Kinerja manajerial dengan Job Relevant Information sebagai variabel moderating. Variabel yang digunakan dalam penelitian ini yaitu partisipasi penyusunan anggaran sebagai variabel bebas, dan Job Relevant Information sebagai variabel moderating, sedangkan pelaksanaan kinerja manajerial sebagai variabel terikat. Penelitian ini menggunakan metode kuantitatif karena menekankan pada pengujian teori-teori melalui pengukuran variabelvariabel penelitian dengan dan melakukan analisis data dengan prosedur statistik. Jenis data yang digunakan dalam penelitian ini adalah data primer. Data primer diperoleh dari penyebaran kuesioner kepada beberapa OPD Kabupaten Pinrang. Metode pengambilan sampel yang digunakan yaitu dengan menggunakan rumus sampling dengan sampel yang diperoleh sebanyak 176 responden. Pengujian hipotesis penelitian dilakukan dengan menggunakan uji statistik regresi berganda dan Analisis regresi moderasi dengan pendekatan residual. Hasil penelitian menunjukkan bahwa partisipasi penyusunan anggaran berpengaruh positif dan signifikan terhadap kinerja manajerial. Berdasarkan kriteria variabel moderating dari hasil MRA, job relevant information dalam penelitian ini merupakan variabel moderating. Job relevant information memperkuat hubungan antara partisipasi penyusunan anggaran dengan kinerja manajerial karena dilihat dari hasil uji $\mathrm{t}$ dan uji anova setelah memasukkan variabel interaksi, diketahui bahwa probabilitas signifikansi di atas 0,05 adalah signifikan.
\end{abstract}

Kata Kunci : Partisipasi Anggaran, Kinerja Manajerial dan Job Relevant Information.

\begin{abstract}
This study aims to determine and test empirically the influence of budgetary participation on managerial performance with Job Relevant Information as a moderating variable. The variables used in this research are the participation of budget preparation as independent variable, and Job Relevant Information as moderating variable, while the implementation of managerial performance as dependent variable. This study uses quantitative methods because it emphasizes the testing of theories through the measurement of research variables with and perform data analysis with statistical procedures. The type of data used in this study is the primary data. Primary data was obtained from the distribution of questionnaires to several OPD Kabupaten Pinrang. Sampling method used is by using the sampling formula with the sample obtained as many as 176 respondents. Hypothesis testing was done by using multiple regression statistic test and regression analysis of moderation with residual approach. The results showed that the participation of budget preparation has a positive and significant effect on managerial performance. Based on criteria of moderating variable from result of $M R A$, job relevant information in this research is moderating variable. Job relevant information strengthens the relationship between budgetary participation with managerial performance as seen from $t$ test result and anova test after input interaction variable, it is known that probability significance above 0,05 is significant.
\end{abstract}

Keywords: Budgetary Participation, Managerial Performance and Job Relevant Information. 


\section{PENDAHUluaN}

Permasalahan yang biasa terjadi pada kinerja manajerial pemerintah daerah adalah realisasi anggaran belanja bagi hasil pajak dan retribusi daerah kepada pemerintah desa berupa pencairan dana motivasi kepada masyarakat yang diberikan secara langsung kepada kelompok masyarakat tanpa melalui pemerintah desa atau masuk dalam anggaran pendapatan dan belanja desa (Sumber: LHP BPK RI Semester 1 hal 48, 2011).

Seperti fenomena yang terjadi di Kabupaten Pinrang contohnya dalam ketidak patuhan terhadap ketentuan perundang-undangan yang mengakibatkan 16 jumlah kasus-kasus dengan nilai mencapai 4.000,66 juta. Yang didalamnya mengakibatkan kerugian daerah dengan nilai mencapai 2.146,39 juta, kekurangan penerimaan dengan nilai $1.601,59$ juta, administrasi dengan ketidakhematan mencapai nilai 60,97 juta, ketidakefektifan dengan nilai 196,70 juta. Dengan nilai penyerahan aset atau penyetoran ke kas negara atau daerah atas temuan yang telah menindaklanjuti dalam proses pemeriksaan dengan kerugian daerah mencapai nilai 60,30 juta, dengan kekurangan penerimaan 1.590,09 juta. Sehingga menyebabkan pemberian opini wajar dengan pengecualian (qualified opinion) dengan 6 kali berturut-turut dari tahun 2005-2010 terhadap Kabupaten Pinrang (Sumber: LHP BPK RI Semester 1 hal 29, 2011).

Menurut Syamsul (2016)

Berdasarkan hasil observasi dan pengamatan yang dilakukan dikantor Badan Kepegawaian Daerah Kabupaten Pinrangg menunjukkan indikasi bahwa belum nampak kesempurnaan dalam kinerja manajerial dengan job relevant information.

Implementasi kebijakan manajerial, mutasi dan promosi jabatan belum sepenuhnya dapat terwujud karena masih terdapat kelemahan dan kekurangan dalam pelaksanaannya. Seharusnya konsep pola penyusunan anggaran harus mengakomodasi dengan baik klasifikasi jabatan dan standar kompetensi sumber daya aparatur sehingga berpengaruh pada pencapaian kinerja pemerintah daerah dan individu yang optimal. Demikian pula tuntutan untuk menciptakan laporan kinerja manajerial daerah yang memiliki kapabilitas dan profesional tidak hanya menjadi kebutuhan instansi pemerintah daerah, tetapi juga menjadi tuntutan masyarakat penerima pelayanan publik. Dengan demikian dari sudut pandang kepala dinas dan aparatur daerah, bahwa keberhasilan pelaksanaan penyusunan anggaran daerah terhadap manajerial dengan job relevant information di Kabupaten Pinrang memerlukan perhatian khusus oleh aparatur yang mempunyai kemampuan, pengetahuan, dan keterampilan serta sikap prilaku terpuji.

Pengembangan

laporan penyusunan anggaran merupakan suatu instrumen penting yang harus dilakukan dengan mekanisme atau tahapantahapan pelaksanaan agar tujuan penganggaran daerah dapat berjalan dengan baik dan menghasilkan informasi yang dapat membantu pemerintah daerah dalam pelaporan anggaran ke pemerintah pusat dapat tercapai serta mengurangi penganggaran yang tidak perlu sehingga prestasi daerah dalam penyusunan anggaran bisa terwujud. 
Sebagai organisasi sektor publik, pemerintah daerah dituntut agar memiliki kinerja yang berorientasi pada kepentingan masyarakat, dan mendorong pemerintah untuk senantiasa tanggap akan tuntutan lingkungannya, dengan berupaya memberikan pelayanan terbaik secara transparan dan berkualitas serta adanya pembagian tugas yang baik pada pemerintah tersebut. Tuntutan yang semakin tinggi diajukan terhadap pertanggungjawaban yang diberikan oleh penyelenggara negara atas kepercayaan yang diamanatkan kepada mereka. Peningkatan kinerja sektor publik merupakan hal yang komprehensif dimana setiap OPD sebagai pengguna anggaran (badan/ dinas/ biro/ kantor) akan menghasilkan tingkat kinerja yang berbeda- beda sesuai dengan kemampuan dan rasa tanggung jawab yang mereka miliki. Dengan kata lain, kinerja instansi pemerintah kini lebih banyak mendapat sorotan karena sering memonitor setiap perencanaan pemerintah dalam satu periode.

Proses

perencanaan

pembangunan daerah perlu diimbangi oleh ketersediaan beberapa hal seperti : kapasitas aparatur pemerintah, sumber daya baik sumber daya manusia maupun sumber dana. Berkaitan dengan hal ini, maka untuk mengukur tingkat pencapaian atas rencana yang ditetapkan dengan sasaran yang ingin dicapai perlu dilakukan evaluasi atas kinerja. Pemberlakuan Undang-Undang Nomor 32 Tahun 2004 tentang pemerintah daerah dan Undang-Undang Nomor 33 tentang perimbangan keuangan antara Pusat dan Daerah, berdampak pada perubahan fundamental dalam hubungan tata pemerintah dan hubungan keuangan sekaligus membawa perubahan penting dalam pengelolaan anggaran pemerintah daerah. Anggaran Pendapatan dan Belanja Daerah (APBD) disusun berdasarkan pendekatan kinerja, yaitu suatu sistem anggaran yang mengutamakan upaya pencapaian hasil kerja atau output dari perencanaan alokasi biaya yang ditetapkan.

Menurut Bastian (2006) kinerja adalah gambaran pencapaian pelaksanaan suatu kegiatan/ program/ kebijaksanaan dalam mewujudkan sasaran, tujuan, misi dan visi organisasi. Secara umum, kinerja merupakan prestasi yang dicapai oleh organisasi dalam periode tertentu. Ukuran kinerja suatu organisasi sangat penting, guna evaluasi dan perencanaan masa depan. Beberapa jenis informasi yang digunakan dalam pengendalian disiapkan dalam rangka menjamin bahwa pekerjaan yang dilakukan telah dilakukan secara efektif dan efisien. Dengan demikian mengukur kinerja tidak hanya informasi finansial tetapi juga informasi nonfinansial. Kinerja pemerintah daerah adalah gambaran mengenai tingkat pencapaian sasaran atau tujuan sebagai penjabaran dari visi, misi, dan strategi instansi pemerintah daerah yang mengindikasikan tingkat keberhasilan atau kegagalan pelaksanaan kegiatankegiatan sesuai dengan tugas pokok dan fungsi aparatur pemerintah (Gusmal, 2007).

Salah satu alat yang digunakan manajemen dalam melakukan perencanaan dan pengendalian jangka pendek dalam organisasi adalah anggaran. Anggaran merupakan pernyataan mengenai estimasi kinerja yang hendak dicapai selama periode waktu tertentu yang dinyatakan dalam ukuran finansial, sedangkan penganggaran adalah proses atau 
metode untuk mempersiapkan suatu anggaran. Penganggaran dalam organisasi sektor publik merupakan tahapan yang cukup rumit dan mengandung nuansa politik yang tinggi. Pada sektor swasta, anggaran merupakan bagian dari rahasia perusahaan yang tertutup untuk publik, namun sebaliknya pada sektor publik anggaran justru harus diinformasikan kepada publik untuk dikritik, didiskusikan, dan diberi masukan. Anggaran sektor publik merupakan instrumen akuntabilitas atas pengelolaan dana publik dan pelaksanaan programprogram yang dibiayai dengan uang publik.

Menurut Mulyadi (2001) anggaran merupakan rencana yang dinyatakan secara kuantitatif, diukur dalam kesatuan moneter atau ukuran yang lain dalam jangka waktu satu tahun. Anggaran merupakan bentuk rencana kegiatan dari pimpinan sampai pada karyawan tingkat bawah. Anthony dan Govindarajan (2005) mendefinisikan anggaran sebagai suatu rencana dalam kuantitas yang dinyatakan dalam satuan moneter dan mencakup satu periode. Anggaran pada sektor publik terkait dengan proses penentuan jumlah alokasi dana untuk tiap-tiap program dan aktivitas dalam satuan moneter yang menggunakan dana milik rakyat (Mardiasmo, 2009). Anggaran digunakan untuk mengendalikan biaya dan menentukan bidang-bidang masalah dalam organisasi tersebut dengan membandingkan hasil kinerja yang telah di anggarkan secara periodik. Agar anggaran itu tepat sasaran dan sesuai dengan tujuan maka diperlukan kerjasama yang baik antara atasan dan bawahan, pegawai dan pimpinan dalam penyusunan anggaran, karena proses penyusunan anggaran merupakan kegiatan yang penting dan kompleks, adanya kemungkinan akan menimbulkan dampak fungsional terhadap sikap dan perilaku anggota organisasi (Dedi, 2008).

Anggaran dibuat oleh kepala daerah melalui usulan dari unit-unit kerja yang disampaikan kepada kepala bagian dan diusulkan kepada kepala daerah, dan setelah itu bersama-sama DPRD menetapkan anggaran yang dibuat sesuai dengan Peraturan Daerah yang berlaku. Proses anggaran daerah disusun berdasarkan pendekatan kinerja dalam Permendagri memuat Pedoman Penyusunan Rancangan APBD yang dilaksanakan oleh tim anggaran eksekutif bersama-sama unit organisasi perangkat daerah (unit kerja).

Dalam penyusunan rencana kerja masing-masing program harus sudah memuat secara rinci uraian mengenai nama program, tujuan dan sasaran program output yang dihasilkan, sumber daya yang dibutuhkan, periode pelaksanaan program, alokasi dan indikator kerja. Seluruh program yang telah dirancang oleh masing-masing unit kerja, selanjutnya diserahkan kepada Panitia Eksekutif. Panitia Eksekutif selanjutnya menganalisis dan bila perlu menyeleksi program-program yang akan dijadikan rencana kerja di masingmasing unit kerja berdasarkan program kerja yang masuk ke Panitia Eksekutif, selanjutnya disusun dan dirancang draf Kebijakan Pembangunan dan Kebijakan Anggaran Tahunan (APBD) yang nantinya akan dibahas pihak legislatif (Permendagri No 13 Tahun 2006).

Di samping itu pada organisasi sektor publik, anggaran dapat digunakan untuk menilai kinerja para pimpinan SKPD, sehingga anggaran mampu mempengaruhi perilaku dan kinerja 
manajerial. Anggaran digunakan untuk mengendalikan biaya dan menentukan bidang-bidang masalah dalam organisasi dengan membandingkan hasil kinerja manajerial yang telah di anggarkan secara periodik.

Anggaran yang telah disusun memiliki fungsi yang sama dengan tujuan organisasi yaitu sebagai perencanaan, pengkoordinasian dan sebagai kriteria kinerja, yaitu anggaran dipakai sebagai suatu sistem pengendalian untuk mengukur kinerja manajerial (Schiff \& Lewin, 1970 dalam Muthaher, 2007). Anggaran dipandang sebagai wujud komitmen dari budget holder (eksekutif) kepada pemberi wewenang (legislative). Sehingga sebagai alat pengendalian, anggaran memberikan rencana detail atas pendapatan dan pengeluaran pemerintah agar pembelanjaan yang dilakukan dapat dipertanggungjawabkan kepada publik.

Dalam hal ini, kinerja pemerintah daerah selaku eksekutif akan dinilai berdasarkan pencapaian target anggaran dan efisiensi pelaksanaan anggaran. Kinerja manajer publik dinilai berdasarkan berapa yang berhasil dicapai, dikaitkan dengan anggaran yang ditetapkan. Partisipasi adalah suatu proses pengambilan keputusan bersama oleh dua bagian atau lebih dimana keputusan tersebut akan memiliki dampak masa depan. Selain partisipasi penyusunan anggaran yang menunjang untuk meningkatkan kinerja pemerintah daerah dalam melakukan perencanaan dan pengendalian jangka pendek dalam organisasi yaitu komitmen organisasi.

Menurut Siagian (2002) faktorfaktor yang dapat mempengaruhi kinerja diantaranya adalah komitmen organisasi, budaya organisasi, akuntabilitas, kepuasan kerja dan kepemimpinan.
Komitmen organisasi adalah komitmen yang diciptakan oleh semua komponenkomponen individual dalam menjalankan operasional organisasi. Tinggi rendahnya komitmen pegawai terhadap organisasi tempat mereka bekerja sangatlah menentukan kinerja yang akan dicapai oleh organisasi (Siagian:2002). Komitmen organisasi dapat terwujud apabila individu dalam organisasi menjalankan hak dan kewajiban mereka sesuai dengan tugas dan fungsinya masing-masing dalam organisasi, karena pencapaian tujuan organisasi merupakan hasil kerja semua anggota organisasi yang bersifat kolektif.

Masalah-masalah yang berkaitan dengan hubungan partisipasi penyusunan anggaran dan kinerja manajerial aparatur pemerintah merupakan masalah yang banyak diperdebatkan, bukti empiris memberikan hasil yang bervariasi dan tidak konsisten. Penelitian yang dilakukan oleh Yulia (2008) yang melakukan penelitian pada SKPD pemerintahan kota Padang. Hasil penelitian tersebut menunjukkan bahwa partisipasi penganggaran berpengaruh signifikan positif terhadap kinerja aparatur pemerintah daerah.

Sedangkan budaya organisasi dan komitmen organisasi tidak mempengaruhi hubungan partisipasi anggaran terhadap kinerja aparat. Penelitian Mila (2005) juga menunjukkan pengaruh signifikan positif antara partisipasi anggaran terhadap kinerja manajerial pada organisasi sektor publik. Berbeda dengan penelitian yang dilakukan oleh Iva (2011) yang membuktikan partisipasi anggaran tidak berpengaruh terhadap kinerja manajerial, sedangkan kultur organisasi juga tidak dapat mempengaruhi 
hubungan partisipasi anggaran terhadap kinerja manajer. Penelitian Arifah (2007) melakukan penelitian pada unit SKPD di Karisidenan Surakarta.

Hasil dari penelitian tersebut menemukan partisipasi penyusunan anggaran berpengaruh signifikan positif terhadap kinerja pemerintah daerah. Penelitian Ulupui (2005), yang melakukan penelitian mengenai pengaruh partisipasi anggaran, persepsi keadilan distributif, keadilan prosedural dan goal commitment terhadap kinerja dinas membuktikan partisipasi berpengaruh terhadap kinerja. Hasil penelitian menunjukkan partisipasi Fenomena yang terjadi di pemerintahan kota Padang dapat dilihat dari kinerja pemerintah kota Padang dari pencapaian pelaksanaan kegiatan pembangunan dan melambatnya pertumbuhan ekonomi yang dapat dilihat dari Realisasi pendapatan asli daerah (PAD) Kota Padang sampai Agustus 2011, baru mencapai 67,50 persen.

Pendapatan yang ditargetkan ke Pemko di 2011 sebanyak Rp 1,1 triliun, tapi hanya mampu direalisasikan per 25 Agustus 2011 sebesar Rp 797 miliar. Hal ini disebabkan keterbatasan sumber daya aparatur di lingkungan Pemerintah daerah dalam pengelolaan keuangan daerah.

(Padang

Ekspres/Red/Redaksi_ILS)

Berdasarkan fenomena di atas serta dari temuan-temuan sebelumnya menunjukkan adanya ketidakkonsistenan antara penelitian satu dengan penelitian lainnya. Ketidakkonsistenan hasil penelitian tersebut ditengahi dengan digunakannya pendekatan kontinjensi (contingency approach). Pendekatan ini menyatakan bahwa perbedaan hubungan penganggaran partisipatif dengan kinerja aparat pemerintah daerah disebabkan oleh perbedaan situasi atau kondisional (Govindarajan,1986).

Partisipasi penyusunan anggaran tidak akan secara langsung meningkatkan kinerja tanpa adanya dukungan faktor-faktor eksternal dan internal yang akan meningkatkan kinerja organisasi. Pelaksanaan mekanisme birokrasi dalam sistem penyusunan anggaran dalam perkembangannya menjadi sangat penting untuk meningkatkan kinerja pemerintah daerah. Akan tetapi, dilihat dari penelitian terdahulu dan fenomena yang ada mekanisme birokrasi masih belum mampu memperbaiki kinerja unit kerja organisasi.

Penyusunan anggaran merupakan suatu proses yang berbeda antara sektor swasta dengan sektor pemerintah, termasuk diantaranya pemerintah daerah. Pada sektor swasta, anggaran merupakan bagian dari rahasia perusahaan yang tertutup untuk publik, namun sebaliknya pada sektor pemerintahan atau publik anggaran justru harus diinformasikan kepada publik untuk dikritik dan didiskusikan dengan tujuan untuk mendapatkan masukan. Anggaran sektor publik merupakan instrumen akuntabilitas atas pengelolaan dana publik dan pelaksanaan program-program yang dibiayai dari uang publik (Mardiasmo, 2005: 61).

Anggaran digunakan sebagai pedoman kerja sehingga proses penyusunannya memerlukan organisasi anggaran yang baik, pendekatan yang tepat, serta model-model perhitungan besaran (simulasi) anggaran yang mampu meningkatkan kinerja pada seluruh jajaran manajemen dalam organisasi. Proses penyusunan anggaran, dapat dilakukan dengan beberapa 
pendekatan yaitu topdown, bottom up dan partisipasi (Ramadhani dan Nasution, 2009).

Dalam sistem penganggaran topdown, dimana rencana dan jumlah anggaran telah ditetapkan oleh atasan/pemegang kuasa anggaran sehingga bawahan/pelaksana anggaran hanya melakukan apa yang telah ditetapkan oleh anggaran tersebut. Penerapan sistem ini mengakibatkan kinerja bawahan/pelaksana anggaran menjadi tidak efektif karena target yang diberikan terlalu menuntut namun sumber daya yang diberikan tidak mencukupi (overloaded). Atasan/pemegang kuasa anggaran kurang mengetahui potensi dan hambatan yang dimiliki oleh bawahan/pelaksana anggaran sehingga memberikan target yang sangat menuntut dibandingkan dengan kemampuan bawahan/pelaksana anggaran.

Oleh karena itu, entitas mulai menerapkan sistem penganggaran yang dapat menanggulangi masalah di atas yakni sistem penganggaran partisipatif (participative budgeting). Melalui sistem ini, bawahan/pelaksana anggaran dilibatkan dalam penyusunan anggaran yang menyangkut subbagiannya sehingga tercapai kesepakatan antara atasan/pemegangkuasa anggaran dan bawahan/pelaksana anggaran mengenai anggaran tersebut (Omposunggu dan Bawono, 2007).

Partisipasi penganggaran adalah proses yang menggambarkan individuindividuyang terlibat dalam penyusunan anggaran dan mempunyai pengaruh terhadap target anggaran. Partisipasi penyusunan anggaran merupakan pendekatan yang secara umum dapat meningkatkan kinerja yang pada akhirnya dapatmeningkatkan efektivitas organisasi (Nor, 2007).

Penyusunan anggaran secarapartisipatif diharapkan dapat meningkatkan kinerja manajer, yaitu ketika suatutujuan dirancang dan secara partisipasi disetujui maka karyawan akanmenginternalisasikan tujuan yang ditetapkan dan memiliki rasa tanggung jawabpribadi untuk mencapainya, karena mereka ikut terlibat dalam penyusunananggaran (Milani, 1975).

Manajer yang baik adalah manajer yang menjalankan fungsi-fungsi manajemen dengan efektif. Fungsi-fungsi manajemen tersebut meliputi perencanaan, investigasi, pengkoordinasian, evaluasi, pengawasan, pemilihan staf, negosiasi, dan perwakilan (Mahoney, et al.) dalam Handoko (1996:34). Fungsi-fungsi manajemen ini merupakan indikator untuk mengukur kinerja manajerial. Kinerja manajerial merupakan salah satu faktor yang dapat dipakai untuk meningkatkan efektivitas organisasi (Sumadiyah dan Susanta, 2004).

Indriantoro (1993) dan Supomo (1998) dalam Kurnia (2010) menyatakan bahwa kinerja manajerial dikatakan efektif jika tujuan anggaran dapat tercapai dan bawahan mendapatkan kesempatan terlibat atau berpartisipasi dalam penganggaran.Partisipasi dari bawahan dalam penyusunan anggaran dapat memberikan kesempatan untuk memasukkan informasi lokal. Bawahan dapat mengkomunikasikan atau mengungkapkan beberapa informasi pribadi yang dapat dimasukkan dalam anggaran yang dipakai sebagai dasar penilaian kinerja bila bawahan ikut serta dalam proses penganggaran. Banyak penelitian dibidang akuntansi manajemen yang memperhatikan 
masalah partisipasi penyusunan anggaran. Hasil-hasil penelitian belum konsisten dan sering terjadi kontradiksi. Penelitian Brownell \& Mc Innes (1986) menemukan bahwa terdapat hubungan positif dan signifikan antara partisipasi dalam penyusunan anggaran dan kinerja manajerial. Milani (1975) dan Brownell \& Hirst (1986) menemukan bahwa partisipasi penyusunan anggaran tidak berpengaruh secara signifikan terhadap kinerja manajerial. Para peneliti menyimpulkan bahwa tidak ada hubungan langsung antara partisipasi penyusunan anggaran dan kinerja manajerial (Gul dkk, (1995) Hapsari (2010).

Hubungan positif dan negatif antara partisipasi penyusunan anggaran dengan kinerja manajerial dipengaruhi oleh kondisi dan situasi tertentu. Hal semacam ini dijelaskan dengan pendekatan kontingensi (contingency approach), di mana pendekatan ini memberi gagasan bahwa sifat hubungan yang ada dalam partisipasi anggaran dengan kinerja manajerial harus sesuai dengan aspek-aspek organisasi dan berbeda bagi tiap situasi. Pendekatan kontingensi mempelajari perilaku manajerial sebagai reaksi atas sejumlah keadaan tertentu guna menyarankan praktek-praktek manajemen yang dianggap paling cocok dalam rangka usaha menghadapi situasi tertentu (Winardi, 2000: 16).

Govindarajan (1986) dan Eker (2008) mengatakan perlu digunakan pendekatan kontingensi untuk menyelesaikan berbagai perbedaan pendapat tersebut. Pendekatan kontingensi antara penyusunan anggaran dengan kinerja manajerial memungkinkan adanya variabel-variabel lain yang dapat bertindak sebagai variabel intervening atau moderating yang mempengaruhi hubungan antara partisipasi anggaran dan kinerja manajerial (Brownell, 1980).

Penelitian terdahulu banyak yang menghubungkan partisipasi penyusunan anggaran dengan kinerja manajerial secara tidak langsung (faktor kontingensi) misalnya menggunakan komitmen tujuan, kultur organisasi, komitmen tujuan, locus of control dan sebagainya. Faktor kontingensi yang digunakan dalam penelitian ini adalah Job Relevant Information (JRI) sebagai variabel moderating karena dianggap dapat memperkuat hubungan antara partisipasi anggaran dan kinerja manajerial.

Informasi (information) yaitu data yang telah diubah menjadi konteksyang berarti dan bermanfaat bagi penggunapengguna tertentu (Daft, 2006). Informasi sangat dibutuhkan oleh berbagai pihak. Dalam pengambilan keputusan dibutuhkan suatu informasi. Bila tidak ada informasi maka pengambilan keputusan tidak dapat dilakukan, kalaupun pengambilan keputusan tersebut dilakukan tanpa adanya informasi yang mendukung maka keputusan yang diambil dapat keliru.

Baiman (1982) dan Kren (1992) mengidentifikasi dua jenis informasi utama dalam organisasi yaitu decision influencing dan job relevant information (JRI), yakni informasi yang memfasilitasi pembuatan keputusan yangberhubungan dengan tugas. Baiman (1982), Yusfaningrum dan Ghozali(2005) menambahkan bahwa JRI membantu bawahan/pelaksana anggaran dalam meningkatkan pilihan tindakannya melalui informasi usaha yang berhasil dengan baik. Kondisi ini memberikan pemahaman yang lebih baik pada 
bawahan mengenai alternatif keputusan dan tindakan yang perlu dilakukan dalam mencapai tujuan.

Apabila dalam perusahaan terdapat informasi yang memfasilitasi pembuatan keputusan yang berhubungan dengan tugas atau job relevant information (JRI) maka manajer yang terlibat dalam pembuatan anggaran akan menyusun target anggaran dengan baik. Dengan adanya job relevant information (JRI) manajer tidak akan melakukan pembiasan target anggaran guna mencapaitarget anggaran dengan mudah namun manajer akan berusaha mencapai target anggaran yang telah ditetapkan sebab job relevant information (JRI) yang ada akan memberikan informasi-informasi bagaimana mencapai target anggaran dengan efektif dan efisien. Usaha untuk mencapai target anggaran tersebut akan mengakibatkan meningkatnya kinerja manajer.

Organisasi pemerintah daerah merupakan organisasi yang bergerak dalam bidang pelayanan publik. Oleh karena itu, kepercayaan yang diberikan oleh masyarakat kepada penyelenggara pemerintah harus diimbangi dengan kinerja yang baik, sehingga pelayanan dapat ditingkatkan secara efektif.

Penyusunan anggaran pada Dinas di Pemerintah Kabupaten Pinrang telah menggunakan penganggaran partisipatif. Informasi yang didapat dari Kepala Bagian Keuangan Dinas Perhubungan Kabupaten Pinrang, menyebutkan bahwa penyusunan anggaran pada SKPD menggunakan sistem bottom up yang dilaksanakan melalui masukan dari seksi, bidang, sub bagian, sekretariat dan Unit Pelaksana Teknis dengan mempertimbangkan rencana kerja tahunan dan rencana strategis $\begin{array}{lcc}\text { Penyusunan } & \text { anggaran } & \text { juga } \\ \text { memperhatikan } & \text { masukan } & \text { dari }\end{array}$ masyarakat melalui Musrenbang (Musyawarah Perencanaan Pembangunan) kemudian dibahas dengan Tim Anggaran Pemerintah Kota dan setelahnya dibahas dengan DPRD Kabupaten Pinrang. Peran manajer dalam penyusunan anggaran sebagai pengarah dan penyelia dari usulanusulan anggaran dengan harapan anggaran dapat mencapai kinerja dan tujuan instansi. Namun, lamanya proses pembahasan anggaran yang disebabkan kurang matangnya perencanaan dapat menyebabkan tertundanya pelaksanaan tugas manajer.

Sekretaris Dinas Ketertiban menjelaskan juga bahwa setiap tingkatan manajemen memiliki tugas pokok dan fungsi (tupoksi) yang berbeda, manajemen tingkat atas bertugas menyampaikan visi dan misi dari instansi, manajemen tingkat menengah bertugas menyampaikan programprogram yang dapat menunjang visi dan misi instansi, sedangkan manajemen tingkat bawah memiliki tugas membuat usulan kegiatan yang terkait dengan program yang telah ditetapkan. Walaupun demikian, setiap manajer telah melakukan tugas dan fungsi pokok seorang manajer, yaitu planning, organizing, executing, dan controlling.

Hal ini dapat dilihat dari tugas setiap manajer dalam mengkoordinir, menyesuaikan, dan mencermati kegiatan maupun program agar dapat menunjang visi dan misi instansi. Transfer informasi yang terjadi di setiap tingkatan manajemen memberikan gambaran dan pengetahuan agar manajer dapat melaksanakan tugasnya dengan baik. Menurut seorang staf operasional anggaran Dinas Kesehatan, informasi 
mengenai kebutuhan pelaksanaan kegiatan dari bawahan/ unit pelaksana terkadang terganjal oleh standar yang telah ditetapkan Pemerintah Kota. Sebagai contoh, kurangnya koordinasi antara pelaksana dengan manajer mengenai standar penggunaan listrik yang telah ditetapkan, namun unit pelaksana teknis membutuhkan alat operasional maka kebijakan penghematan pemakaian listrik harus dilakukan di kantor Dinas Kesehatan yang berdampak pada kinerja manajerial tidak maksimal.

Berdasarkan uraian penjelasan diatas, peneliti ingin mengetahui bagaimana partisipasi penyusunan anggaran di dinas Pemerintah Kabupaten Sidenreng Rappang memberikan pengaruh pada kinerja manajerial dengan menggunakan job relevant information sebagai variabel moderating. Berdasarkan uraian latar belakang yang telah dijelaskan di atas, peneliti akan melakukan penelitian dengan judul "Pengaruh Partisipasi Penyusunan Anggaran Terhadap Kinerja Manajerial Dengan Job Relevant Information Sebagai Variabel Moderating (Studi pada Dinas Pemerintah Kabupaten Pinrang )".

Berdasarkan uraian latar belakang di atas, peneliti dapat mengidentifikasi permasalahan-permasalahan sebagai berikut:

1. Lamanya proses pembahasan anggaran yang disebabkan kurang matangnya perencanaan dapat menyebabkan kinerja manajerial berkurang yang seharusnya manajer sudah mendapatkan tugas yang jelas.

2. Standar anggaran yang diberikan dari atasan membuat manajer membuat kebijakan yang berdampak pada kinerja manajerial tidak maksimal.

3. Transfer informasi terkadang tidak tersampaikan dengan baik dikarenakan kurangnya koordinasi antara manajer dan pelaksana.

Berdasarkan uraian penjelasan latar belakang dan identifikasi masalah di atas, maka peneliti membatasi masalah penelitian pada pengujian pengaruh partisipasi penyusunan anggaran terhadap kinerja manajerial dengan menggunakan job relevant information sebagai variabel moderating. Objek penelitian pada dinas di Pemerintah Kabupaten Pinrang.

\section{TINJAUAN PUSTAKA}

\subsection{Teori Pengharapan (Expectancy Theory of Motivation)}

Teori pengharapan atau teori ekspektansi telah dikembangkan oleh Levin dan Tolman (1930). Kemudian secara sistematis dan konprehensif di rumuskan oleh Vroom dalam bukunya yang berjudul Work and Motivation dalam Gitosudarmo dan Sudita (1997). Teori ini menyatakan bahwa intensitas kecenderungan untuk melakukan dengan cara tertentu tergantung pada intensitas harapan bahwa kinerja akan diikuti dengan hasil yang pasti dan pada daya tarik dari hasil kepada individu.

Vroom dalam Koontz, 1990 mengemukakan bahwa orang-orang akan termotivasi untuk melakukan hal-hal tertentu guna mencapai tujuan apabila mereka yakin bahwa tindakan mereka akan mengarah pada pencapaian tujuan tersebut.

Sehubungan dengan tingkat ekspektansi seseorang Craig C. Pinder (1948) dalam bukunya Work 
Motivation berpendapat bahwa ada beberapa faktor yang mempengaruhi tingkat harapan atau ekspektansi seseorang yaitu:

a. Harga diri.

b. Keberhasilan waktu melaksanakan tugas.

c. Bantuan yang dicapai dari seorang supervisor dan pihak bawahan.

d. Informasi yang diperlukan untuk melaksanakan suatu tugas

e. Bahan-bahan baik dan peralatan baik untuk bekerja.

Sementara teori harapan menyatakan bahwa motivasi karyawan adalah hasil dari seberapa jauh seseorang menginginkan imbalan (Valence), yaitu penilaian bahwa kemungkinan sebuah upaya akan menyebabkan kinerja yang diharapkan (Expectancy), dan keyakinan bahwa kinerja akan mengakibatkan penghargaan (Instrumentality). Singkatnya, Valence adalah signifikansi yang dikaitkan oleh individu tentang hasil yang diharapkan.

Ini adalah kepuasan yang diharapkan dan tidak aktual bahwa seorang karyawan mengharapkan untuk menerima setelah mencapai tujuan. Harapan adalah keyakinan bahwa upaya yang lebih baik akan menghasilkan kinerja yang lebih baik. Harapan dipengaruhi oleh faktor-faktor seperti kepemilikan keterampilan yang sesuai untuk melakukan pekerjaan, ketersediaan sumber daya yang tepat, ketersediaan informasi penting dan mendapatkan dukungan yang diperlukan untuk menyelesaikan pekerjaan. Jadi harapan seseorang mewakili keyakinan seorang individu bahwa tingkat upaya tertentu akan diikuti oleh suatu tingkat kinerja tertentu.
Dasar pemikiran teori pengharapan adalah bahwa motivasi ditentukan oleh hasil yang diharapkan diproleh seseorang sebagai akibat dari tindakannya. Oleh karena itu, teori pengharapan memfokuskan pada tiga hubungan yaitu : (1) Hubungan upayakinerja, (2) Hubungan Kinerja-ganjaran, (3) Hubungan ganjaran-tuuan pribadi.

\subsection{Teori Penetapan Tujuan (Goal- Setting)}

Teori penetapan Tujuan (Goal Setting) dikembangkan oleh Locke pada tahun 1968. Teori ini menjelaskan tujuan yang ditetapkan dengan prestasi kerja (Kinerja). Konsep dasar teori penetapan tujuan adalah bahwa seseorang yang memahami tujuan (apa yang diharapkan organisasi kepadanya) akan mempengaruhi prilaku kepadanya.Locke menunjukkan adanya keterkaitan antara tujuan dan kinerja seseorang terhadap tugas.

Dia menemukan bahwa tujuan spesifik dan sulit menyebabkan kinerja tugas lebih baik dari tujuan yang mudah. Beberapa tahun setelah Locke menerbitkan artikelnya, penelitian lain yang dilakukan Dr. Gary Latham, yang mempelajari efek dari penetapan tujuan di tempat kerja. Penelitiannya mendukung persis apa yang telah dikemukakan oleh Locke mengenai hubungan tak terpisahkan antara penetapan tujuan dan kinerja. Pada tahun 1990, Locke dan Latham menerbitkan karya bersama mereka, ' $A$ Theory of Goal Setting and Task Performance'.

Dalam buku ini, mereka memperkuat argumen kebutuhan untuk menetapkan tujuan spesifik dan sulit.Lima Prinsip Penetapkan Tujuan yaitu : 


\section{a. Kejelasan}

Tujuan harus jelas terukur, tidak ambigu, dan ada jangka waktu tertentu yang ditetapkan untuk penyelesaian tugas. Manfaatnya ketika ada sedikit kesalahpahaman dalam perilaku maka orang masih akan tetap menghargai atau toleran. Orang tahu apa yang diharapkan, dan orang dapat menggunakan hasil spesifik sebagai sumber motivasi.

\section{b. Menantang}

Salah satu karakteristik yang paling penting dari tujuan adalah tingkat tantangan. Orang sering termotivasi oleh prestasi, dan mereka akan menilai tujuan berdasarkan pentingnya sebuah pencapaian yang telah diantisipasi. Ketika orang tahu bahwa apa yang mereka lakukan akan diterima dengan baik, akan ada motivasi alami untuk melakukan pekerjaan dengan baik. Dengan catatan sangat penting untuk memperhatikan keseimbangan yang tepat antara tujuan yang menantang dan tujuan yang realistis.

\section{c. Komitmen}

Tujuan harus dipahami agar efektif. Karyawan lebih cenderung memiliki tujuan jika mereka merasa mereka adalah bagian dari penciptaan tujuan tersebut. Gagasan manajemen partisipatif terletak pada ide melibatkan karyawan dalam menetapkan tujuan dan membuat keputusan. Mendorong karyawan untuk mengembangkan tujuan-tujuan mereka sendiri, dan mereka menjadi berinisiatif memperoleh informasi tentang apa yang terjadi di tempat lain dalam organisasi. Dengan cara ini, mereka dapat yakin bahwa tujuan mereka konsisten dengan visi keseluruhan dan tujuan perusahaan.

\section{d. Umpan balik (feedback)}

Umpan balik memberikan kesempatan untuk mengklarifikasi harapan, menyesuaikan kesulitan sasaran, dan mendapatkan pengakuan. Sangat penting untuk memberikan kesempatan benchmark atau target, sehingga individu dapat menentukan sendiri bagaimana mereka melakukan tugas.

\section{e. Kompleksitas Tugas}

Faktor terakhir dalam teori penetapan tujuan memperkenalkan dua persyaratan lebih untuk sukses. Untuk tujuan atau tugas yang sangat kompleks, manajer perlu berhati-hati untuk memastikan bahwa pekerjaan tidak menjadi terlalu berlebihan.

Orang-orang yang bekerja dalam peran yang kompleks mungkin sudah memiliki motivasi tingkat tinggi. Namun, mereka sering mendorong diri terlalu keras jika tindakan tidak dibangun ke dalam harapan tujuan untuk menjelaskan kompleksitas tugas, karena itu penting untuk memberikan orang waktu yang cukup untuk memenuhi tujuan atau meningkatkan kinerja. Sediakan waktu yang cukup bagi orang untuk berlatih atau mempelajari apa yang diharapkan dan diperlukan untuk sukses. Inti dari penetapan tujuan adalah untuk memfasilitasi keberhasilan. Oleh karena itu pastikan bahwa kondisi sekitar tujuan tidak menyebabkan frustrasi atau menghambat orang untuk mencapai tujuan mereka.

Penentuan tujuan adalah sesuatu yang diperlukan untuk kesuksesan. Dengan pemahaman teori penetapan tujuan, kemudian dapat secara efektif menerapkan prinsip-prinsip untuk tujuan yang akan ditetapkan. 


\subsection{Kinerja Manajerial}

\section{a. Definisi Kinerja Manajerial}

Manajer adalah seseorang yang bekerja dengan dan melalui orang lain dengan mengoordinasikan kegiatankegiatan pekerjaan guna mencapai tujuan organisasi. Hal ini dapat berarti mengoordinasikan pekerjaan dari satu kelompok atau departemen, atau dapat berarti menyelia satu orang saja. Pengoordinasian tersebut dapat juga mencakup pengoordinasian kegiatankegiatan pekerjaan suatu tim yang terdiri atas orang-orang dari organisasi berbeda, seperti karyawan temporer atau karyawan yang bekerja di pemasok dari organisasi tersebut (Arfan Ikhsan Lubis, 2011: 46).

Malayu (2007:44) mengemukakan bahwa manajer adalah sumber aktivitas dan mereka harus merencanakan, mengorganisasi, mengarahkan, dan mengendalikan semua kegiatan, agar tujuan tercapai. Manajer harus memberikan arah kepada perusahaan yang dipimpinnya.

Kinerja adalah gambaran pencapaian pelaksanaan suatu kegiatan/ program/ kebijaksanaan dalam mewujudkan sasaran, tujuan, misi dan visi organisasi. Secara umum, kinerja merupakan prestasi yang dicapai oleh organisasi dalam periode tertentu. (Indra Bastian, 2006: 274)

Mardiasmo (2006) mengatakan bahwa kinerja manajerial adalah gambaran seorang manajer mengenai tingkat pencapaianpelaksanaan suatu kegiatan atau program, kebijakan dalam mewujudkan sasaran, tujuanmisi, dan visi organisasi yang tertuang dalam strategic planning suatu organisasi. Sedangkan menurut Mahoney (1963) dalam Nurcahyani (2010), kinerja manajerial diartikan sebagai kinerja individu dalam kegiatan manajerial yang meliputi perencanaan, investigasi, koordinasi, supervisi, pengaturan staf, negosiasi, dan representasi.

Jadi, kinerja manajerial dapat diartikan juga sebagai tingkat pencapaian manajer dalam melaksanakan dengan perencanaan, pengorganisasian, pengarahan, dan pengendalian kegiatan untuk mencapai tujuan organisasi.

\section{b. Klasifikasi Manajer}

Secara umum, manajer dapat diklasifikasikan sebagai manajer tingkat bawah, tingkat menengah, dan tingkat atas. (Arfan Ikhsan Lubis, 2011: 46)

1) Manajer tingkat bawah (Lower Management)

Manajer ini merupakan orang yang menduduki posisi di tingkatan paling bawah dan mengelola pekerjaan individu non-manajerial yang terlibat dalam produksi atau penciptaan produk organisasi. Mereka sering disebut penyelia, tetapi bisa juga disebut manajer lini, manajer kantor, atau bahkan mandor.

2) Manajer tingkat menengah (Middle Management)

Manajer tingkat menengah mencakup semua tingkatan manajemen antara tingkatan paling rendah dengan tingkat puncak pada organisasi tertentu. Manajer tingkat menengah mengelola pekerjaan para manajer lini pertama dan mempunyai sebutan, seperti kepala bagian atau kepala biro, pemimpin proyek, manajer pabrik, atau manajer divisi.

3) Manajer tingkat atas (Top Management)

Manajer yang menduduki posisi ini biasanya disebut manajemen puncak, yang bertanggungjawab atas pengambilan keputusan yang mencakup seluruh organisasi dan menyusun 
rencana serta sasaran yang akan memengaruhi keseluruhan organisasi itu.

\section{c. Faktor-faktor yang Mempengaruhi Kinerja Manajerial}

Ada beberapa faktor yang dapat mempengaruhi kinerja manajerial menurut Amstrong dan Baron (1998) dalam Nanda Hapsari (2010), antara lain:

1) Faktor Pribadi (keahlian, kepercayaan diri, motivasi dan komitmen)

2) Faktor Kepemimpinan (kualitas keberanian/semangat, pedoman pemberiansemangat pada manajer dan pemimpin kelompok organisasi).

3) Faktor Tim/kelompok (sistem pekerjaan dan fasilitas yang disediakan oleh organisasi)

4) Faktor Situasional (perubahan dan tekanan dari lingkungan internal daneksternal).

\section{d. Pengukuran Kinerja Manajerial}

Supomo dan Indriantoro (1998) menjelaskan, menurut teori manajemen klasik kinerja manajerial didasarkan pada fungsi-fungsi manajemen sebagai berikut:

1) Perencanaan

Meliputi pemilihan strategi, kebijakan, program, dan prosedur untuk mencapai tujuan organisasi. Semua tingkatan manajemen dalam struktur organisasi melakukan perencanaan baik tingkat bawah, menengah, maupun manajer tingkat atas.

2) Investigasi

Laporan dari setiap manajer pada pusat pertanggung jawaban yang dipimpinnya menjelaskan kinerja manajer yang bersangkutan. Untuk menyusun laporan tersebut, manajer melaksanakan salah satu fungsi manajemen yaitu investigasi. Dalam hal ini, manajemen bertugas untuk mengumpulkan dan menyampaikan informasi untuk catatan, laporan dan rekening, mengukur hasil, menentukan persediaan, dan analisa pekerjaan.

3) Koordinasi

Setiap fungsi manajerial adalah pelaksana koordinasi. Kebutuhan akan mensinkronisasi tindakan individu timbul dari perbedaan dalam pendapat mengenai bagaimana cita-cita kelompok dapat dicapai atau bagaimana tujuan individu atau kelompok dipadukan. Koordinasi ini bisa dilakukan dengan tukar menukar informasi dengan bagian organisasi yang lain untuk mengaitkan dan menyesuaikan program, memberitahu departemen lain, dan berhubungan dengan manajer lain.

4) Evaluasi

Evaluasi merupakan salah satu fungsi pokok manajemen yang digunakan untuk menilai dan mengukur proposal, kinerja, penilaian pegawai, penilaian catatan hasil, penilaian laporan keuangan, dan pemeriksaan produk.

5) Pengawasan

Pengawasan meliputi mengarahkan, memimpin dan mengembangkan bawahan, membimbing, melatih, member tugas, dan menangani keluhan.

6) Penataan staf (Staffing)

Penataan staf merupakan suatu proses yang terdiri dari spesifikasi pekerjaan (job description), pergerakan tenaga, spesifikasi pekerja, seleksi dan penyusunan organisasi untuk mempersiapkan dan melatih karyawan agar melaksanakan pekerjaan dengan baik.

7) Negosiasi

Bentuk negosiasi yang dilakukan manajer antara lain terjadi pada saat melakukan pembelian, penjualan atau melakukan kontrak untuk barang dan jasa, menghubungi pemasok, tawar 
menawar dengan wakil penjual maupun secara kelompok.

8) Perwakilan

Perwakilan adalah fungsi manajemen untuk menghadiri pertemuan dengan perusahaan lain, pertemuan perkumpulan bisnis, pidato untuk acara kemasyarakatan, pendekatan ke masyarakat, dan mempromosikan tujuan umum perusahaan.

\subsection{Partisipasi Penyusunan Anggaran a. Teori Kontijensi}

Teori kontijensi dapat digunakan untuk menganalisis desain dan sistem akuntansi manajemen untuk memberikan informasi yang dapat digunakan perusahaan untuk berbagai macam tujuan Otley (1980) Suryanawa (2008). Dalam partisipasi penyusunan anggaran, penggunaan teori kontijensi telah lama menjadi perhatian para peneliti. Berdasarkan hasil penelitian tersebut, maka sebuah teori kontijensi dalam pengaruh partisipasi anggaran terhadap kinerja aparat pemerintah daerah.

Para peneliti di bidang akuntansi menggunakan teori kontijensi saat menghubungkan pengaruh partisipasi anggaran terhadap kinerja aparat pemerintah daerah. Pengaruh partisipasi anggaran terhadap kinerja aparat pemerintah daerah mempunyai faktorfaktor kontijensi, faktor-faktor tersebut adalah faktor kepuasan kerja. Faktor kepuasan kerja adalah variabel moderating, yang dapat memperkuat atau memperlemah pengaruh partisipasi anggaran dan kinerja aparat pemerintah daerah. Anggaran merupakan pernyataan mengenai estimasi kinerja yang hendak dicapai selama periode waktu tertentu yang dinyatakan dalam ukuran finansial (Mardiasmo, 2009).
Lebih rinci lagi, Halim (2013: 22) mengartikan anggaran yaitu rencana kegiatan yang diwujudkan dalam bentuk finansial, meliputi usulan pengeluaran yang diperkirakan untuk suatu periode waktu, serta usulan cara-cara memenuhi pengeluaran tersebut. Dalam konteks otonomi daerah dan desentralisasi, anggaran menduduki posisi yang penting. Proses dan metode untuk mempersiapkan suatu anggaran disebut dengan penganggaran. Dalam sektor publik, penganggaran merupakan tahapan yang cukup rumit dan penuh dengan nuansa politik. Berbeda dengan sektor swasta atau bisnis, anggaran dianggap sebagai rahasia perusahaan yang tertutup bagi publik, sedangkan pada sektor publik anggaran dianggap sebagai alat akuntabilitas publik di dalam mengelola dana publik dan programprogram yang didanai dengan uang publik sehingga anggaran pada sektor publik justru harus diinformasikan untuk didiskusikan secara terbuka.

Anggaran publik merupakan kegiatan yang di representasikan dalam bentuk rencana perolehan pendapatan dan belanja dalam satuan moneter. Dalam bentuk yang paling sederhana, anggaran publik merupakan suatu dokumen yang menggambarkan kondisi keuangan dari suatu organisasi yang meliputi informasi mengenai pendapatan, belanja, dan aktivitas. (Mardiasmo, 2009) Anggaran berisi estimasi mengenai apa yang akan dilakukan organisasi di masa yang akan datang. Setiap anggaran memberikan informasi mengenai apa yang hendak dilakukan dalam beberapa periode yang akan datang.

Menurut Undang-Undang (UU) Nomor 17 Tahun 2003 tentang Keuangan Negara, menyatakan bahwa anggaran 
adalah alat akuntabilitas, manajemen, dan kebijakan ekonomi. Anggaran sebagai instrumen kebijakan ekonomi berfungsi untuk mewujudkan pertumbuhan dan stabilitas perekonomian serta pemerataan pendapatan dalam rangka mencapai tujuan bernegara.

Anggaran dapat diinterpretasikan sebagai paket pernyataan perkiraan dan penerimaan dan pengeluaran yang diharapkan akan terjadi dalam satu atau beberapa periode mendatang. Di dalam tampilannya, anggaran selalu menyertakan data penerimaan dan pengeluaran yang terjadi di masa lalu. Kebanyakan organisasi sektor publik melakukan pembedaan krusial antara tambahan modal dan penerimaan, serta tambahan pendapatan dan pengeluaran. (Indra Bastian, 2006: 163-164)

Anggaran merupakan suatu rencana yang disusun secara sistematis yang meliputi seluruh kegiatan perusahaan dan dinyatakan dalam unit (satuan) moneter dan berlaku untuk jangka waktu (periode) mendatang. Dari pengertian tersebut, dapat diketahui bahwa anggaran merupakan hasil kerja (output) terutama berupa taksirantaksiran yang akan dilaksanakan masa mendatang. Karena anggaran merupakan hasil kerja (output), anggaran dituangkan dalam suatu naskah tulisan yang disusun secara teratur dan sistematis. Sementara itu, penganggaran adalah proses kegiatan yang menghasilkan anggaran tersebut sebagai hasil kerja, serta proses kegiatan yang berkaitan dengan pelaksanaan fungsifungsi anggaran, yaitu fungsi-fungsi pedoman kerja, alat pengoordinasian kerja, dan alat pengawasan kerja(Arfan Ikhsan Lubis, 2011: 226)
Dari uraian di atas dapat disimpulkan bahwa anggaran merupakan pernyataan mengenai perkiraan rencana kerja yang berisi penerimaan dan pengeluaran yang disusun secara sistematis untuk periode yang akan datang.

\section{b. Karakteristik Anggaran}

Anggaran sektor publik menurut (Indra Bastian, 2009 : 81) mempunyai karakteristik sebagai berikut:

1) Anggaran dinyatakan dalam satuan keuangan dan satuan selain keuangan.

2) Anggaran umumnya mencakup jangka waktu tertentu, satu atau beberapa tahun.

3) Anggaran berisi komitmen atau kesanggupan manajemen untuk mencapai sasaran yang ditetapkan.

4) Usulan anggaran ditelaah dan disetujui oleh pihak yang berwenang lebih tinggi dari penyusun anggaran.

5) Sekali disusun, anggaran hanya dapat diubah dalam kondisi tertentu.

\section{c. Manfaat Anggaran}

Ada beberapa alasan penyebab anggaran dianggap penting (Mardiasmo, 2009), yaitu:

1) Anggaran merupakan alat bagi pemerintah untuk mengarahkan pembangunan sosial-ekonomi, menjamin kesinambungan, dan meningkatkan kualitas hidup masyarakat;

2) Anggaran diperlukan karena adanya kebutuhan dan keinginan masyarakat yang tidak terbatas dan terus berkembang, sedangkan sumber daya yang ada terbatas; dan

3) Anggaran diperlukan untuk meyakinkan bahwa pemerintah telah bertanggungjawab terhadap rakyat. 


\section{d. Fungsi Anggaran}

Mardiasmo (2009) dalam Abdul Halim (2013:50-52) mengidentifikasi beberapa fungsi anggaran dalam manajemen sektor publik adalah sebagai berikut:

1) Alat perencanaan;

Anggaran sektor publik dibuat untuk merencanakan tindakan apa yang akan dilakukan oleh pemerintah, berapa biaya yang dibutuhkan, dan berapa hasil yang diperoleh dari belanja pemerintah tersebut. Anggaran sebagai alat perencanaan digunakan untuk:

a) Merumuskan tujuan serta sasaran kebijakan agar sesuai dengan visi dan misi yang ditetapkan.

b) Merencanakan berbagai program dan kegiatan untuk mencapai tujuan organisasi serta alternatif pembiayaannya.

c) Mengalokasikan dana pada berbagai program dan kegiatan yang telah disusun; dan

d) Menentukan indikator kinerja dan tingkat pencapaian strategi.

2) Alat pengendalian;

Anggaran sebagai instrumen pengendalian digunakan untuk menghindari adanya pengeluaran yang terlalu besar (overspending), terlalu rendah (underspending), salah sasaran (missappropriation), atau adanya penggunaan yang tidak semestinya (misspending). Anggaran merupakan alat untuk mengawasi kondisi keuangan dan pelaksanaan operasional program atau kegiatan pemerintah. Sebagai alat pengendalian manajerial, anggaran sektor publik digunakan untuk meyakinkan bahwa pemerintah mempunyai uang yang cukup untuk memenuhi kewajibannya. Pengendalian anggaran sektor publik dapat dilakukan dengan empat cara, yaitu: a) Membandingkan kinerja aktual dengan kinerja yang dianggarkan.

b) Menghitung selisih anggaran.

c) Menemukan penyebab yang dapat dikendalikan dan tidak dapat dikendalikan atas suatu varians.

d) Merevisi standar biaya atau target anggaran untuk tahun berikutnya.

3) Alat kebijakan fiskal

Melalui anggaran organisasi sektor publik dapat menentukan arah atas kebijakan tertentu. Anggaran sebagai alat kebijakan fiskal pemerintah, digunakan untuk menstabilkan ekonomi dan mendorong pertumbuhan ekonomi. Melalui anggaran sektor publik dapat diketahui arah kebijakan fiskal pemerintah, sehingga dapat dilakukan prediksi dan estimasi ekonomi.

4) Alat politik

Pada sektor publik, anggaran merupakan dokumen politik sebagai bentuk komitmen eksekutif dan kesepakatan legislatif atas penggunaan dana publik untuk kepentingan tertentu. Anggaran digunakan untuk memutuskan prioritas-prioritas dan kebutuhan keuangan terhadap prioritas tertentu. Anggaran tidak sekedar masalah teknik, melainkan diperlukan keterampilan berpolitik, membangun koalisi, keahlian bernegosiasi, dan pemahaman tentang manajemen keuangan sektor publik yang memadai oleh para manajer publik. Oleh karena itu, kegagalan dalam melaksanakan anggaran akan dapat menjatuhkan kepemimpinan dan kredibilitas pemerintah.

5) Alat koordinasi dan komunikasi

Melalui dokumen anggaran yang komprehensif, sebuah bagian atau unit kerja atau departemen yang merupakan sub-organisasi dapat mengetahui apa yang harus dilakukan dan apa yang akan 
dilakukan oleh bagian/unit kerja lainnya. Oleh karena itu, anggara dapat digunakan sebagai alat koordinasi dan komunikasi antara dan seluruh bagian dalam pemerintahan.

\section{6) Alat penilaian kinerja}

Kinerja eksekutif dinilai berdasarkan pencapaian target anggaran, efektivitas dan efisiensi pelaksanaan anggaran. Kinerja manajer publik dinilai berdasarkan berapa hasil yang dicapai dikaitkan dengan anggaran yang telah ditetapkan. Anggaran merupakan alat yang efektif untuk pengendalian dan penilaian kinerja.

7) Alat motivasi.

Anggaran dapat digunakan sebagai alat untuk memotivasi manajer dan stafnya agar dapat bekerja secara ekonomis, efektif, dan efisien dalam mencapai target dan tujuan organisasi yang ditetapkan. Agar dapat memotivasi pegawai, anggaran hendaknya bersifat challenging.

8) Alat menciptakan ruang publik.

Fungsi ini hanya berlaku pada organisasi sektor publik, karena pada organisasi swasta anggaran merupakan dokumen rahasia yang tertutup untuk publik. Masyarakat dan elemen masyarakat lainnya nonpemerintah, seperti LSM, Perguruan Tinggi, Organisasi Keagamaan, dan organisasi masyarakat lainnya, harus terlibat dalam proses penganggaran publik. Keterlibatan mereka dapat bersifat langsung dan tidak langsung. Keterlibatan langsung masyarakat dalam proses penganggaran dapat dilakukan mulai dari proses penyusunan perencanaan pembangunan maupun rencana kerja pemerintah (daerah), sedangkan keterlibatan secara tidak langsung dapat melalui perwakilan mereka di lembaga legislatif (DPR/DPRD).

\section{e. Siklus Anggaran Sektor Publik}

Siklus anggaran adalah masa atau jangka waktu mulai saat anggarandisusun sampai dengan saat perhitungan anggaran disahkan dengan undang-undang.Menurut Mardiasmo (2004) siklus anggaran meliputi empat tahap, yaitu:

1) Tahap Persiapan Anggaran (Budget Preparation).

Pada tahap persiapan anggaran dilakukan taksiran pengeluaran atas dasartaksiran pendapatan yang tersedia. Terkait dengan masalah tersebut, yang perludiperhatikan adalah sebelum menyetujui taksiran pengeluaran, hendaknya terlebihdahulu dilakukan penaksiran pendapatan secara lebih akurat. Selain itu, harusdisadari adanya masalah yang cukup berbahaya jika anggaran pendapatandiestimasi pada saat bersamaan dengan pembuatan keputusan tentang anggaranpengeluaran.

2) Tahap Ratifikasi Anggaran (budget ratification).

Pada tahap ini pimpinan eksekutif harus mempunyai kemampuan untukmenjawab dan memberikan argumentasi yang rasional atas segala pertanyaan-pertanyaan dan bantahanbantahan dari pihak legislatif.

3) Tahap Pelaksanaan Anggaran (budget implementation).

Dalam tahap pelaksanaan anggaran ini, hal terpenting yang harusdiperhatikan manajer keuangan publik adalah dimilikinya sistem informasiakuntansi dan sistem pengendalian manajemen. Manajer keuangan publik dalamhal ini 
bertanggung jawab untuk menciptakan sistem akuntansi yang memadai danhandal untuk perencanaan dan pengendalian anggaran yang telah disepakati, danbahkan dapat diandalkan untuk tahap penyusunan anggaran periode berikutnya.

4) Tahap Pelaporan dan Evaluasi Anggaran

Tahap ini terkait dengan aspek akuntabilitas. Jika tahap implementasitelah didukung dengan sistem akuntansi dan sistem pengendalian manajemenyang baik, maka diharapkan tahap budget reporting and evaluation tidak akanmenemui banyakmasalah.

\section{f. Pendekatan dalam Penyusunan Anggaran}

Secara garis besar, pendekatan dalam penyusunan anggaran dibagi menjadi 3 kelompok, yaitu:

1) Top down approach (bersifat dari atas-ke-bawah)

Dalam penyusunan anggaran ini, manajemen senior menetapkan anggaran bagi tingkat yang lebih rendah sehingga pelaksana anggaran hanya melakukan apa saja yang telah disusun. Tapi pendekatan ini jarang berhasil karena mengarah kepada kurangnya komitmen dari sisi pembuat anggaran dan hal ini membahayakan keberhasilan rencana anggaran.

2) Bottom up approach (bersifat dari bawah-ke-atas)

Pada bottom up approach, anggaran sepenuhnya disusun oleh bawahan dan selanjutnya diserahkan atasan untuk mendapatkan pengesahan. Dalam pendekatan ini, manajer tingkat yang lebih rendah berpartisipasi dalam menentukan besarnya anggaran. Pendekatan dari bawah ke atas dapat menciptakan komitmen untuk mencapai tujuan anggaran, tetapi apabila tidak dikendalikan dengan hati-hati dapat menghasilkan jumlah yang sangat mudah atau yang tidak sesuai dengan tujuan keseluruhan perusahaan.

3) Kombinasi top down dan bottom up Kombinasi antara kedua pendekatan inilah yang paking efektif. Pendekatan ini menekankan perlunya interaksi antara atasan dan bawahan secara bersama sama menetapkan anggaran yang terbaik bagi perusahaan.

\section{g. Pengertian Partisipasi Penyusunan Anggaran}

Partisipasi dalam proses penyusunan anggaran dianggap sebagian orangsebagai obat mujarab untuk memenuhi kebutuhan akan harga diri dan aktualisasidari para anggota organisasi. Dengankata lain, pekerja dan manajer tingkat bawah memiliki suara dalam prosesmanajemen. Partisipasi secara luas pada dasarnya merupakan prosesorganisasional, di mana para individual terlibat dan mempunyai pengaruh dalampembuatan keputusan yang mempunyai pengaruh secara langsung terhadap paraindividu tersebut (Supomo dan Indriantoro, 1998).

Partisipasi adalah suatu "proses pengambilan keputusan bersama oleh dua bagian atau lebih pihak dimana keputusan tersebut akan memiliki dampak masa depan terhadap mereka yang membuatnya." Arfan dan Muhammad, (2008: 173-175)

Menurut Brownell (1982) dalam Eka Yuda (2013) partisipasi merupakan proses dimana individu-individu terlibat langsung didalamnya dan mempunyai pengaruh pada penyusunan target anggaran yang kinerjanya akan dievaluasi dan kemungkinan akan 
dihargai atas dasar pencapaian target anggaran mereka. Jadi, partisipasi penyusunan anggaran adalah keterlibatan pihak - pihak secara langsung dalam proses pengambilan kebijakan penyusunan anggaran.

\section{h. Manfaat Partisipasi Penyusunan Anggaran}

Manfaat dari partisipasi dalam penyusunan anggaran menurut Arfan Ikhsan dan Muhammad Ishak (2005: 175) adalah:

a. Partisipan menjadi terlibat secara emosi dan bukan hanya secara tugas dalam pekerjaan mereka. Partisipasi dapat meningkatkan moral dan mendorong inisiatif yang lebih besar pada semua tingkatan manajemen.

b. Partisipasi juga berarti meningkatkan rasa kesatuan kelompok, yang pada gilirannya cenderung meningkatkan kerja sama antar-anggota kelompok dalam penetapan tujuan. Tujuan organisasi yang dibantu penetapannya oleh orang-orang tersebut, kemudian akan dipandang sebagai tujuan yang selaras dengan tujuan pribadi mereka.

c. Partisipasi berarti juga berkaitan dengan penurunan tekanan dan kegelisahan yang berkaitan dengan anggaran. Hal ini disebabkan orang yang berpartisipasi dalam penetapan tujuan mengetahui bahwa tujuan tersebut wajar dan dapat dicapai.

d. Partisipasi juga dapat menurunkan ketidakadilan yang dipandang ada dalam alokasi sumber daya organisasi antara subunit organisasi, serta reaksi negatif yang dihasilkan dari persepsi semacam itu. Manajer yang terlibat dalam penetapan tujuan akan memiliki pemahaman yang lebih baik mengenai penyebab sumber daya dialokasikan dengan cara demikian.

e. Melalui proses negosiasi dan banyak diskusi anggaran yang terjadi dalam rapat, manajer akan menyadari masalah dari rekan-rekannya di unit organisasi lainnya dan memiliki pemahaman yang lebih baik atas saling ketergantungan antardepartemen. Dengan demikian, banyak masalah potensial yang berkaitan dengan anggaran dapat dihindari.

\section{i. Kendala dalam Anggaran} Partisipatif

Ikhsan dan Ishak (2005: 175) menjelaskan bahwa anggaran partisipatif mempunyai tiga potensi masalah, yaitu:

1) Menetapkan standar yang terlalu tinggi atau terlalu rendah. Jika anggaran dibuat terlalu tinggi atau ketat akan menurunkan kinerja manajer, sebaliknya jika anggaran dibuat terlalu mudah akan menurunkan minat dan tantangan bagi manajer sehingga berakibat terhadap penurunan kinerja manajer.

2) Membuat kelonggaran dalam anggaran (budgetary slack). Budgetary slack muncul ketika seorang manajer dengan sengaja memperkirakan pendapatan terlalu rendah atau memperkirakan biaya terlalu tinggi.

3) Partisipasi semu (pseudoparticipation).

Pseudoparticipation terjadi pada perusahaan yang tidak sungguhsungguh dalam menerapkan partisipasi. Manajer tingkat bawah terpaksa menyatakan persetujuan terhadap keputusan yang ditetapkan oleh manajemen puncak karena perusahaan memerlukan persetujuan 
mereka. Hal ini akan mengakibatkan banyak sekali permasalahan perilaku, antara lain: meningkatnya rasa ketegangan bawahan, dan timbulnya perpecahan antara manajemen puncak dengan bawahan, seperti rasa saling curiga. Partisipasi semu akan terjadi kalau semakin banyak orang yang duduk dalam komite anggaran.

\section{j. Pengukuran Partisipasi Penyusunan Anggaran}

Pengukuran partisipasi dalam penyusunan anggaran diukur berdasarkan instrumen yang dikembangkan oleh Milani (1975). Pengukuran bertujuan untuk menilai partisipasi manajer dalam berbagai keputusan yang diambil oleh perusahaan. Menurut Milani (1975) partisipasi manajer dapat dilihat dari beberapa aspek, yaitu:

1) Keterlibatan manajer dalam penyusunan anggaran.

2) Wewenang manajer dalam penyusunan anggaran dan berlakunya anggaran.

3) Keterlibatan manajer dalam pengawasan proses penyusunan anggaran.

4) Keterlibatan manajer dalam tujuan pelaksanaan anggaran pada bidang yang dipimpin.

5) Proses penyusunan anggaran akan menetapkan siapa yang akan berperan dalam melaksanakan sebagian kegiatan pencapaian sasaran anggaran dan ditetapkan pula sumber daya yang disediakan bagi pemegang peran tersebut untuk memungkinkan melaksanakan perannya. Peran tersebut menuntut manajer untuk bisa mengarahkan bawahan agar bekerja dengan maksimal guna mencapai tujuan yang ditetapkan.

\subsection{Job Relevant Information}

\section{a. Pengertian Informasi}

Jogiyanto (1999:

mendefinisikan informasi sebagai hasil dari pengolahan data dalam suatu bentuk yang lebih berguna dan lebih berarti bagi penerimanya yang menggambarkan suatu kejadian - kejadian (event) yang nyata (fact) yang digunakan untuk pengambilan keputusan. Sedangkan menurut Tata Sutabri (2005) informasi adalah data yang telah diklasifikasikan atau diolah atau diinterpretasikan untuk digunakan dalam proses pengambilan keputusan. Jadi, informasi adalah data yang telah diolah dan memiliki arti untuk membantu dalam proses pengambilan keputusan.

\section{b. Karakteristik Informasi}

Organisasi-organisasi bergantung pada informasi kualitas tinggi untuk mengembangkan rencana strategis, mengidentifikasikan masalah dan berinteraksi dengan organisasi lain. Informasi disebut berkualitas tinggi apabila informasi tersebut memiliki karakteristik-karakteristik yang menjadikannya bermanfaat untuk tugas ini. Karakteristik-karakteristik informasi yang bermanfaat dapat dibagi menjadi tiga kategori luas yaitu (Daft, 2006):

1) Waktu

Informasi harus ada dan tersedia ketika dibutuhkan, up todate, danberkaitan dengan periode waktu yang tepat (masa lalu,sekarang atau masadepan).

2) Isi

Informasi yang bermanfaat bebas dari kesalahan, sesuai dengankebutuhan pengguna, lengkap, ringkas, relevan (yaitu informasi tersebutmeniadakan data yang dibutuhkan), dan merupakan ukuran kinerja yangakurat. 
3) Bentuk

Informasi harus tersedia dalam bentuk yang mudah dipahami pengguna dan dalam tingkat detail yang memenuhi kebutuhan pengguna.Penyajiannya harus disusun dan menggunakan kombinasi kata, angka, dandiagram yang sangat membantu pengguna. Selain itu, informasi harusdisajikan dengan menggunakan medium yang bermanfaat (dokumen tercetak, pertunjukan video, suara).

\section{c. Pengertian Job Relevant Information}

Kren, (1992) mengidentifikasi dua tipe utama dari informasi dalam organisasi, yaitu: (1) informasi perilaku manajer dalam pengambilan keputusan untuk evaluasi kinerja; dan (2) informasi untuk mengambil tindakan agar tercapai hasil lebih baik. Berkaitan dengan hal tersebut. Sementara Baiman, (1982) dalam Yusfaningrum dkk. (2005) menambahkan bahwa job relevant information membantu bawahan dalam meningkatkan pilihan tindakannya melalui informasi usaha yang berhasil dengan baik. Kondisi ini memberikan pemahaman yang lebih baik pada bawahan mengenai alternatif keputusan dan tindakan yang perlu dilakukan dalam mencapai tujuan.

Menurut Murray (1990) dalam Rakib Husin (2010) informasi juga dapat ditransfer dari bawahan kepada atasannya. Hal ini menunjukkan, bahwa ada dua keuntungan yang dapat diperoleh dari adanya transfer informasi dari bawahan kepada atasan yaitu:

1) atasan dapat mengembangkan strategi yang lebih baik yang dapat disampaikan kepada bawahan sehingga kinerja akan meningkat
2) Dari informasi yang diberikan bawahan kepada atasan akan memperoleh tingkat keputusan yang lebih baik atau lebih sesuai bagi organisasi. Tersediannya informasi yang berhubungan dengan tugas akan meningkatkan perencanaan untuk mencapai tujuan yang ditetapkan.

Bila bawahan atau pelaksana anggaran diberi kesempatan untuk memberikan masukan berupa informasi yang dimilikinya kepada atasan atau pemegang kuasa anggaran sehingga atasan atau pemegang kuasa anggaran akan memperoleh pemahaman yang lebih baik tentang pengetahuan yang relevan dengan tugas (Krisler BornadiOmposunggu dan Icuk Rangga Bawono, 2006).

Dapat disimpulkan bahwa job relevant information adalah informasi yang berkaitan dengan tugas yang dapat membantu manajer dalam pengambilan keputusan. Transfer informasi yang terjadi diharapkan agar pihak yang bersangkutan mendapat pengetahuan yang lebih baik mengenai alternatif keputusan dan tindakan yang dibutuhkan untuk mencapai tujuan.

\section{d. Pengukuran Job Relevant Information}

Menurut teori yang dikembangkan oleh Kren (1992), Job relevantinformation diukur dengan menggunakan indikator sebagai berikut:

1) Mendapat informasi yang jelas. Informasi harus dapat dibaca dan dipahami dengan baik agar informasi tersebut berguna bagi para pembuat keputusan.

2) Mempunyai informasi yang memadai. Informasi yang tersedia harus lengkap dan sesuai dengan kuantitas dan 
kualitas yang dibutuhkan pengguna informasi pada waktu tertentu.

3) Memperoleh informasi yang strategik. Informasi yang diperoleh dapat digunakan untuk mengambil keputusan jangka panjang dan memberikan kontribusi bagi tujuan organisasi.

4) Mencari informasi yang tepat. Informasi haruslah sesuai dengan apa yang dibutuhkan dan dapat diperoleh pada saat yang tepat.

\subsection{Penelitian Terdahulu}

Penelitian ini mengambil beberapa referensi dari penelitian terdahulu sebagai acuan dalam melakukan penelitian. Penelitian yang dijadikan referensi yaitu penelitian yang relevan dengan variabel yang digunakan pada penelitian ini.

1. Gita Pramudya Saraswati (2015)

Penelitian yang dilakukan oleh Yogi Andrianto pada tahun 2015 dengan judul "Analisis Pengaruh Partisipasi Penyusunan Anggaran Terhadap Kinerja Manajerial dengan Kepuasan Kerja, Job Relevant Information dan Kepuasan Kerja sebagai Variabel Moderating (Studi Empiris Pada Wilayah SKPD Kota Yogyakarta)" menggunakan 50 orang manajer sebagai responden. Dari penelitian tersebut diketahui bahwa keterlibatan Kepala SKPD dan kepala bagian di SKPD di wilayah kota Yogyakarta dalam penyusunan anggaran mempengaruhi kinerja manajerial. Sedangkan job relevant information tidak bisa berperan sebagai variabel moderating terhadap pengaruh partisipasi penyusunan anggaran dan kinerja manajerial. Motivasi kerja dan kepuasan kerja bisa berperan sebagai variabel moderating terhadap pengaruh partisipasi penyusunan anggaran dan kinerja manajerial.

Kesamaan penelitian ini dengan penelitian yang dilakukan oleh Gita (2015) adalah penggunaan variabel job relevant information sebagai variabel moderating. Sedangkan perbedaannya adalah penelitian tersebut menambahkan variabel kepuasan kerja sebagai variabel moderating. Selain itu, penelitian yang dilakukan Gita dilakukan pada SKPD di wilayah Kota Yogyakarta.

2. Penelitian Febri Hendri (2015)

Penelitian yang dilakukan oleh Febri Hendri yang berjudul "Pengaruh Partisipasi Anggaran Terhadap Senjangan Anggaran Dengan Komitmen Organisasi Sebagai Variabel Moderating (Studi Empiris Pada Pemerintahan Daerah Kabupaten Sleman Di Yogyakarta)" pada tahun 2015 didapatkan hasil bahwa partisipasi dalam anggaran sangat dibutuhkan komitmen organisasi agar tidak terjadinya senjangan anggaran yang begitu besar, dan senjangan anggaran tersebut dapat diminimalisir bahkan dihilangkan. Penelitian tersebut menggunakan 103 karyawan sebagai responden.

Persamaan penelitian ini dengan penelitian yang dilakukan oleh Febri adalah sama-sama menggunakan variabel partisipasi anggaran sebagai variabel independen dan lokasi penelitian pada pemerintahan. Sedangkan perbedaannya, penelitian tersebut menggunakan variabel komitmen organisasi dan senjangan anggaran sebagai variabelnya.

3. Penelitian Kunwafiyan Nurcahyani (2016)

Penelitian yang dilakukan oleh Kunwafiyan Nurcahyani pada tahun 2016 dengan judul "Pengaruh Partisipasi 
Anggaran Terhadap Kinerja Manajerial Melalui Komitmen Organisasi Dan Persepsi Inovasi Sebagai Variabel Intervening". Dari penelitian yang menggunakan 160 karyawan sebagai respondenmenunjukkan bahwa partisipasi anggaran berpengaruh langsung terhadap kinerja manajerial, sedangkan partisipasi anggaran tidak berpengaruh terhadap kinerja manajerial melaluikomitmen organisasi dan persepsi inovasi.

Persamaan penelitian ini dengan penelitian yang dilakukan oleh Kunwafiyan adalah sama-sama menggunakan variabel partisipasi anggaran sebagai variabel independen dan kinerja manajerial sebagai variabel dependen serta lokasi penelitian pada sektor pemerintahan. Sedangkan perbedaannya, penelitian tersebut menggunakan variabel komitmen organisasidan persepsi inovasi sebagai variabel intervening. Sedangkan penelitian ini menggunakan variabel job relevant information sebagai variabel moderating.

4. Penelitian Ridwan Mattola (2016)

Penelitian yang dilakukan oleh Ridwan Mattola pada tahun 2011 yang berjudul "Pengaruh Partisipasi Anggaran Terhadap Kinerja dengan Locus of Control Sebagai Variabel Moderating (Studi Kasus pada PT Kimia Farma Trading \& Distribution Cabang Makasar)" menggunakan 49 manajer sebagai responden. Dari penelitian tersebut, didapatkan hasil bahwa partisipasi anggaran berpengaruh positif terhadap kinerja. Locusof control berpengaruh positif terhadap hubungan antara partisipasianggaran dengan kinerja. Dengan kata lain, partisipasi anggaran yang dimoderasi oleh locus of control berpengaruh positif terhadap kinerja.
Persamaan penelitian ini dengan penelitian yang dilakukan oleh Ridwan adalah sama-sama menggunakan variabel partisipasi anggaran sebagai variabel independen dan kinerja manajerial sebagai variabel dependen. Sedangkan perbedaannya, penelitian tersebut menggunakan locus of control sebagai variabel moderating dan objek penelitian padaperusahaan. Sedangkan penelitian ini menggunakan variabel job relevant Information sebagai variabel moderating, sedangkan objek penelitian pada sektor pemerintahan

\subsection{Kerangka Konseptual Dan Hipotesis}

a. Kerangka Konseptual

Kerangka pemikiran merupakan penjelasan sementara terhadap gejalagejala yang menjadi obyek permasalahan. Kreteria utama kerangka pemikiran adalah alur-alur pemikiran yang logis dalam membangun suatu kerangka berpikir yang membuahkan kesimpulan berupa hipotesis (Sugiono 2004:47). Dalam Penelitian ini terdapat beberapa variabel yang digunakan di antaranya variabel terikat adalah variabel yang menjadi perhatian utama dalam sebuah pengamatan (kuncoro, 2003). Pengamatan akan dapat mendeteksikan ataupun menerangkan variabel dalam variabel terikat beserta perubahannya yang terjadi kemudia. Variabel terikat dalam peneltian ini adalah kinerja manajerial $(\mathrm{Y})$.

Variabel bebas adalah variabel yang dapat mempengaruhi perubahan dalam variabel terikat dan mempunyai pengaruh positif dan negative bagi variabel terikat nantinya ( Kuncoro, 2003). Variabel bebas adalah partipasi penyusunan anggaran (X1). Dan variabel pemoderasi adalah variabel yang dapat 
memperkuat atau memperlemah hubungan antara variabel dependen dan independen ( Ghozali, 2007).

Tujuan pengguanaan variabel pemoderasi yaitu untuk melihat pengaruh tidak langsung antar variabel serta memperjelas hubungan variabel independen dengan variabel dependen. Variabel pemoderasi dalam penelitian ini adalah Job Relevant Information.

Dalam penelitian ini, partisipasi penyusunan anggaran dianggap mampu atau tidak mampu menciptakan kinerja manajerial baik secara langsung maupun tidak langsung melalui Job Relevant Information.

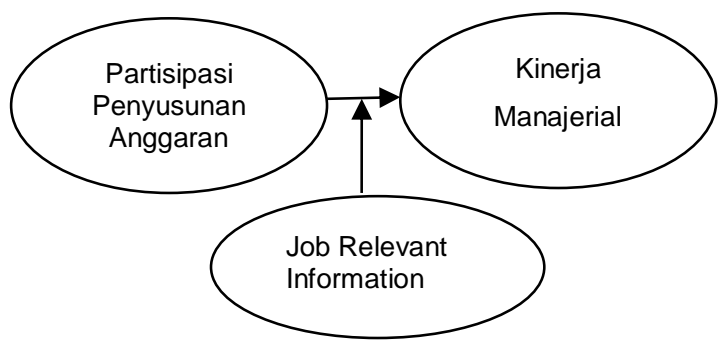

Gambar 1. Kerangka Konseptual

\section{b. Hipotesis}

Berdasarkan uraian pada tinjauan teoritis di atas yang didukung oleh teoriteori dan hasil penelitian, maka berikut ini dapat digambarkan rangkaian variabel-variabel yang akan dikaji yaitu:

1. Partisipasi Penyusunan Anggaran dan Kinerja Manajerial.

Anggaran yang telah disusun sebagai perencanaan dan indikator kinerja, dimana anggaran berfungsi sebagai alat pengendalian untuk mengukur kinerja manajer dalam mencapai tujuan anggaran. Untuk mencegah terjadinya dampak yang ditimbulkan dalam penyusunan anggaran, perlu dilibatkannya manajer bawah sehingga anggaran partisipatif dapat meningkatkan kinerja anggota dalam organisasi.
Partisipasi penyusunan anggaran merujuk kepada tingkat pengaruh keterlibatan setiap individu dalam proses perancangan anggaran. Partisipasi tersebut diartikan sebagai suatu bentuk kerjasama yang terjadi antara atasan dan bawahan. Dengan penyusunan anggaran secara partisipatif diharapkan kinerja manajer akan meningkat, karena saat tujuan atau standar yang dirancang secara partisipatif disetujui, maka bawahan akan memiliki tanggung jawab pribadi untuk mencapai tujuan atau standar tersebut karena ikut serta terlibat dalam penyusunannya.

Penelitian yang dilakukan Yusfaningrum dan Ghozali (2005) menemukan bahwa terdapat hubungan yang positif antara partisipasi penyusunan anggaran dan kinerja manajerial, semakin tinggi partisipasi manajer dalam penyusunan anggaran, maka akan semakin tinggi pula kinerja manajerial perusahaan.

Berdasarkan gagasan tersebut, dapat ditarik hipotesis hubungan antara partisipasi anggaran terhadap kinerja manajerial sebagai berikut:

Hipotesis 1 : Partisipasi penyusunan anggaran berpengaruh positif terhadap kinerja manajerial.

2 Partisipasi Penyusunan Anggaran, Job Relevant Information, dan Kinerja Manajerial.

Adanya proses partisipasi dalam penyusunan anggaran, bawahan diberi kesempatan untuk memberikanmasukan kepada atasan berupa informasi yang dimilikinya tentang tugas yang dijalankan, sehingga atasanakan memperoleh pemahaman yang lebih baik tentang informasi yang berhubungan dengan tugas (job relevant information). Secara umum, informasiselama proses partisipasi akan meningkatkan kemampuan individual terhadap kinerja. 
Invoice: Jurnal Ilmu Akuntansi

p-ISSN: 2714-6359 e-ISSN: 2714-6340

Vol.2 Nomor 2 September 2020

Job Relevant Information

mempengaruhikinerja karena

memberikan prediksi akurat atas kondisi

lingkungan danmemberikan seleksi yang

lebih efektif untuk melakukan tindakan terbaik.

Kren (1992) menghubungkan hasil penelitiannya dengan fakta bahwa Job RelevantInformation membantu bawahan untuk mengubah pilihantindakan merekamelalui tindakan yang berisi informasi, sehingga meningkatkan kinerja.Seorang manajer yang memiliki informasi yang akurat dan lengkap yangberhubungan dengan tugas serta keikutsertaannya (partisipasi) dalampenyusunan anggaran, maka akan meningkatkan kinerja manajerial dalammencapai target anggaran yang ditetapkan.

Partisipasi anggaran pada dasarnya merupakan perwujudan dari bentukketerlibatan para manajer dalam penyusunan anggaran secara keseluruhan dandiharapkan cepat meningkatkan kinerja manajerial. Keterlibatan bawahan dalampenyusunan anggaran akan sangat memungkinkan mereka untuk memberikaninformasi yang diketahui. Dalam hal ini, bawahan mungkin saja mengungkapkanbeberapa informasi pribadinya yang dapat dimasukkan dalam penetapan anggaran.Campbell dan Gingrich (1986) Kren (1992) menemukan bahwa JRI berperansebagai variabel moderating terhadap pengaruh positif antara Partisipasi penyusunananggaran dan kinerja manajerial.

Berdasarkan uraian penjelasan di atas, maka gambar paradigma penelitian yang akan digunakan pada penelitian ini, dapat digambarkan sebagai berikut :
Dari gagasan di atas, maka

peneliti mengajukan hipotesis mengenai hubungan ketiga variabel tersebut dengan rumusan sebagai berikut :

Hipotesis 2 : Job Relevant Information memperkuat pengaruh partisipasi anggaran terhadap kinerja manajerial

\section{METODE PENELITIAN}

\subsection{Metode Analisis Data}

\section{a. Uji Kualitas Pengumpulan Data}

Dikarenakan data diambil secara primer dengan menggunakan kuesioner, maka digunakan pengujian kualitas data sebagai berikut:

1) Uji Validitas

Menurut Sugiyono (2008), instrumen valid berarti instrumen tersebut dapat digunakan untuk mendapatkan data secara benar dan teliti. Suatu skala pengukuran disebut valid apabila skala tersebut melakukan apa yang seharusnya dilakukan dan mengukur apa yang seharusnya diukur. Teknik yang digunakan untuk uji validitas pada penelitian ini adalah teknik korelasi product moment dari person.

2) Uji Asumsi Klasik

a) Uji Linieritas

Uji linieritas bertujuan untuk mengetahui apakah variabel-variabel penelitian yang digunakan mempunyai hubungan yang linier ataukah tidak secara signifikan. Uji ini biasanya digunakan prasyarat dalam analisis korelasi atau regresi linier. Pengujian dengan menggunakan Test for Linearity dengan taraf signifikansi 0,05. Dua variabel dikatakan mempunyai hubungan yang linier bila signifikansinya kurang dari 0,05 (Gendro Wiyono, 2011). 
b) Uji Multikolonieritas

Uji multikolinearitas merupakan bentuk pengujian untuk asumsi dalam analisis regresi berganda. Multikolinearitas terjadi apabila terdapat hubungan yang kuat antara variabel independen dalam model regresi. Apabila terjadi gejala multikolinearitas, salah satu langkah untuk memperbaiki model adalah dengan menghilangkan variabel dari model regresi, sehingga bisa dipilih model yang paling baik (Purbayu Budi Santosa dan Ashari, 2005). Ada tidaknya multikolinearitas dapat dideteksi dengan menggunakan Pearson Correlation, dilihat dari besarnya Toleranca Value dan Variance Inflation Factor (VIF).

Tolerance Value dan VIF menunjukkan setiap variabelindependen manakah yang dijelaskan oleh variabel independen lainnya atau dalam pengertian sederhana setiap variabel independen menjadi variabel dependen (terikat). Tolerance Value mengukur variabilitas variabel independen yang terpilih yang tidak dijelaskan oleh variabel independen lainnya. Jadi, nilai tolerance yang rendah sama dengan nilai VIF tinggi karena VIF $=1 /$ Tolerance Value. Nilai yang umum dipakai untuk menunjukkan adanya multikolinieritas adalah nilai Tolerance Value $\geq 0,10$ atau sama dengan nilai VIF $\leq 10$ maka tidak terjadi multikolinieritas antar variabel independennya (Imam Ghozali, 2006).

c) Uji Heteroskedastisitas

Heteroskedastisitas adalah suatu kondisi apabila variabel pengganggu mempunyai varian yang berbeda dari satu amatan ke amatan yang lain atau varian antara variabel dalam model tidak konstan (Gujarati, 2003). Asumsi varian dikatakan konstan apabila distribusi residual tidak dipengaruhi oleh besar kecilnya variabel independen. Dalam regresi, salah satu asumsi yang harus dipenuhi adalah bahwa varians dari residual dari satu pengamatan ke pengamatan yang lain tidak memiliki pola tertentu. Pola yang tidak sama ini ditunjukkan dengan nilai yang tidak sama varians dengan residual. Gejala varians yang tidak sama ini disebut dengan gejala heterokedastisitas, sedangkan adanya gejala variansresidual yang sama dari satu pengamatan ke pengamatan yang lain disebut homokedastisitas (Purbayu Budi Santosa dan Ashari, 2005). Salah satu uji statistik yang dapat digunakan untuk mendeteksi ada tidaknya heterokedastisitas adalah Uji Spearman yang mengusulkan untuk meregres nilai absolut residual terhadap variabel independen, dengan persmaan regresi :

\section{$\mathrm{Ut}=\alpha+\beta \mathrm{Xt}+\mathrm{vi}$}

Jika variabel independen secara signifikan secara statistik tidak mempengaruhi variabel dependen, maka tidak terdapat indikasi terjadi heterokedastisitas. Hal ini dapat dilihat apabila dari probabilitas signifikansinya di atas tigkat kepercayaam 5\% (Iman Ghozali, 2006)

\section{b. Analisis Data Deskriptif}

Analisis statistik deskriptif digunakan dalam penelitian ini untukmemberikan gambaran atau deskripsi mengenai variabel-variabel penelitian yaitu: Partisipasi Penyusunan Anggaran, Kinerja Kepala dinasial, dan Job Relevant Information. Penelitian ini menggunakan tabel distribusi frekuensi yangmenunjukkan kisaran teoritis, kisaran aktual, nilai rata-rata (mean) dan standardeviasi (Ghozali, 2006). 


\section{c. Uji Hipotesis}

1) Analisis Regresi Sederhana

Persamaan regresi sederhana dapat digunakan untuk melakukan prediksi seberapa tinggi hubungan kausal satu variabel independen dengan satu variabel dependen. Dalampenelitian ini analisis regresi sederhana digunakan untuk menguji pengaruh Partisipasi Penyusunan Anggaran terhadap Kinerja Kepala dinasial. Langkah-langkah dalam melakukan analisis regresi sederhana yaitu:

a) Membuat garis linier sederhana $y=\beta_{0}+\beta_{1} X_{1}+\beta_{2} X_{2}+\beta_{3} X_{1} x_{2}+e$

Keterangan :

Y : nilai yang diprekdisikan

a : konstanta atau apabila harga $\mathrm{X}=0$

b : koefisien regresi

$\mathrm{X}$ : nilai variabel independen

(Sugiyono, 2008)

\section{b) Menguji signifikan uji t}

Uji $\mathrm{t}$ dilakukan untuk menguji signifikansi konstanta dan setiap variabel independen akan berpengaruh terhadap variabel dependen.

Uji t pada dasarnya menunjukkan seberapa jauh pengaruh satu variabel bebas secara individual dalam menerangkan variasi variabel dependen. Jika $t$ hitung lebih kecil daripada $t$ tabel dengan taraf signifikansi $5 \%$ maka mempunyai pengaruh yang tidak signifikan. Sebaliknya jika t hitung lebih besar atau sama dengan $t$ tabel pada taraf signifikansi 5\% maka mempunyai pengaruh yang signifikan.

Hipotesis diuji dengan menggunakan uji t untuk menguji apakah secara terpisah variabel bebas mampu menjelaskan variabel terikat secara baik. Kesimpulan atas pengujian hipotesis didasarkan pada tingkat signifikan dan koefisien yaitu sebagai berikut :
- Jika tingkat signifikan $<\alpha(0,05)$ dan koefisien regresi $(\beta)$ negative maka hipotesis diterima yang berarti tersedia cukup bukti untuk menolak H0 pada pengujian 1,2.. atau dengan kata lain tersedia bukti untuk menerima $\mathrm{H} 1, \mathrm{H} 2$.

- Jika tingkat signifikan $<\alpha(0,05)$ dan koefisien regresi $(\beta)$ positif maka hipotesis ditolak dan berarti tidak tersedia cukup bukti untuk menerima hipotesis.

- Jika tingkat signifikan $>\alpha(0,05)$ dan koefisien regresi $(\beta)$ negative maka hipotesis ditolak yang berarti tidak tersedia cukup bukti untuk menerima hipotesis.

2) Analisis Regresi Moderasi dengan Pendekatan Residual

Menurut Ghozali (2007:167) pengujian variabel moderasi menggunakan uji interaksi dan uji selisih nilai mutlak (absolute residual) mempunyai kecendrungan akan terjadi multikolinearitas yang tinggi antar variabel independen dan hal ini akan menyalahi asumsi klasik dalam regresi ordinary least square (OLS). Untuk mengatasi multikolinearitas ini, maka dikembangkanlah model lain yang disebut uji residual Ghozali, (2007:169). Peneliti menggunakan uji residual untuk membuktikan apakah variabel moderasi kemampuan manajemen merupakan variabel moderasi atau bukan.

Fokus dalam uji residual adalah menilai ketidakcocokan (lack of fit) yang dihasilkan dari deviasi (penyimpangan) dari suatu model. Ghozali, (2007:171) hubungan linear antara variabel independen dan variabel moderasi. Lack of fit ditunjukkan oleh nilai residual di dalam regresi. 
Invoice: Jurnal Ilmu Akuntansi

p-ISSN: 2714-6359 e-ISSN: 2714-6340

Vol.2 Nomor 2 September 2020

Pendekatan residual ini dikemukakan oleh Dewar dan Werbel (1979). Pendekatan ini mengasumsikan bahwa ada banyak kemungkinan kombinasi yang menunjukkan kesesuaian terbaik atau konsistensi yang ada ini disajikan dalam jalur regresi. Kesesuaian terbaik dari masing-masing variabel bebas (partisipasi anggaran) dan faktor kondisional diperoleh dengan peregresian faktor kontinjen dari variabel bebas. Estimasi parameter berasal dari regresi kemudian digunakan untuk menentukan nilai faktor kontinjen (komitmen organisasi dan job relevant informationt) berkaitan dengan nilai variabel bebas (persamaan 2). Apabila kombinasi tersebut menyimpang dari kesesuaian terbaik akan menurunkan kualitas laporan keuangan pemerintah daerah. Hubungan negatif dan signifikan dari korelasi antara nilai deviasi (nilai absolute dari seridual standardized) dari masing-masing pasangan (masingmasing variabel bebas dan komitmen organisasi dan job relevant informationt) pada kinerja manajerial pemerintah daerah sebagai bukti mendukung hipotesis.

Deviasi (simpangan) yaitu ketidakcocokan variabel bebas dengan faktor kontijen (persamaan 3,5 dan 7). Ketidaksesuaian antara variabel bebas dengan faktor kontijen berhubungan negatif dengan kinerja manajerial pemerintah daerah, artinya semakin rendah tingkat ketidaksesuaian (deviasi) atau dengan kata lain semakin tinggi tingkat kesesuaian antara variabel bebas dan faktor kontijen (komitmen organisasi dan job relevant informationt) akan meningkatkan kinerja manajerial pemerintah daerah, dan begitupula sebaliknya.

Perhitungan dengan SPSS 21 akan diperoleh keterangan atau hasil tentang koefisien determinasi $\left(\mathrm{R}^{2}\right), \mathrm{Uji} F$, Uji $t$ untuk menjawab perumusan masalah penelitian. berikut ini keterangan yang berkenaan dengan hal tersebut koefisien determinasi yaitu Setelah koefisien korelasi diketahui, maka langkah selanjutnya adalah menghitung koefisien determinasi, yaitu untuk mengetahui seberapa besar pengaruh variabel $\mathrm{X}$ terhadap variabel $Y$. Koefisien determinasi $\left(\mathrm{R}^{2}\right)$ pada intinya mengukur seberapa jauh kemampuan model dalam menerangkan variasi variabel dependen.

\section{HASIL DAN PEMBAHASAN}

\subsection{Hasil Penelitian}

a. Analisis Deskriptif Variabel Kinerja Manajerial (Y)

Analisis deskriptif jawaban responden tetang variabel kinerja manajerial didasarkan pada jawaban responden atas pertanyaan-pertanyaan seperti yang terdapat dalam kuesioner yang disebarkan pada responden. Variasi jawaban responden untuk variabel kinerja manajerial dapat dilihat pada tabel 14 sebagai berikut:

Tabel 14 Tanggapan responden Kinerja Manajerial (Y)

\begin{tabular}{|c|c|c|c|c|c|c|c|c|c|c|c|c|}
\hline \multirow{3}{*}{$\begin{array}{c}\text { Pernyataan/indik } \\
\text { ator }\end{array}$} & \multicolumn{10}{|c|}{ Skor } & \multirow{3}{*}{$\begin{array}{c}\text { Tota } \\
1\end{array}$} & \multirow{3}{*}{$\begin{array}{l}\text { Rata } \\
\text {-rata }\end{array}$} \\
\hline & \multicolumn{2}{|c|}{ STS } & \multicolumn{2}{|c|}{ TS } & \multicolumn{2}{|c|}{$\mathbf{N}$} & \multicolumn{2}{|c|}{$S$} & \multicolumn{2}{|c|}{ SS } & & \\
\hline & $\mathbf{F}$ & $\%$ & $\mathbf{F}$ & $\%$ & $\mathbf{F}$ & $\%$ & $\mathbf{F}$ & $\%$ & $\mathbf{F}$ & $\%$ & & \\
\hline $\begin{array}{l}\text { Biasanya target } \\
\text { yang ditetapkan }\end{array}$ & 8 & 4,5 & 11 & 6,3 & 43 & 24,4 & 109 & 61,9 & 5 & 2,8 & 620 & 124 \\
\hline
\end{tabular}




\begin{tabular}{|c|c|c|c|c|c|c|c|c|c|c|c|c|}
\hline mudah dicapai. & & & & & & & & & & & & \\
\hline $\begin{array}{l}\text { Kinerja Saya baik } \\
\text { pada umumnya } \\
\text { dinilai baik jika } \\
\text { anggaran yang } \\
\text { ditetapkan dapat } \\
\text { dicapai dan } \\
\text { dilaksanakan }\end{array}$ & 22 & 12,5 & $\begin{array}{c}11 \\
7\end{array}$ & 66,5 & 26 & 14,8 & 7 & 4 & 4 & 2,3 & 382 & 76,4 \\
\hline $\begin{array}{l}\text { Kinerja Saya baik } \\
\text { pada umumnya di } \\
\text { nilai baik jika } \\
\text { anggaran yang } \\
\text { ditetapkan dapat di } \\
\text { pertanggung } \\
\text { jawabkan }\end{array}$ & 36 & 20,5 & 20 & 11,4 & 10 & 5,7 & 2 & 1,1 & 108 & $\begin{array}{c}61 \\
4\end{array}$ & 854 & $\begin{array}{c}130 \\
8\end{array}$ \\
\hline $\begin{array}{l}\text { Untuk mengetahui } \\
\text { perkembangan } \\
\text { kinerja yang baik } \\
\text { pada umumnya } \\
\text { baik jika rencana } \\
\text { dan realisasi } \\
\text { anggaran dari tahun } \\
\text { ke tahun dapat } \\
\text { diperbandingkan. }\end{array}$ & 7 & 4 & 14 & 8 & 117 & 66,5 & 38 & 21,6 & 0 & 0 & 538 & $\begin{array}{c}107 \\
6\end{array}$ \\
\hline $\begin{array}{l}\text { Saya berperan } \\
\text { dalam penentuan } \\
\text { tujuan, kebijakan, } \\
\text { rencana kegiatan } \\
\text { seperti } \\
\text { penjadwalan kerja, } \\
\text { penyusunan } \\
\text { anggaran dan } \\
\text { penyusunan } \\
\text { program. }\end{array}$ & 7 & 4 & 16 & 9,1 & 14 & 8 & 103 & 58,5 & 36 & $\begin{array}{c}20 \\
5\end{array}$ & 677 & $\begin{array}{c}135 \\
4\end{array}$ \\
\hline $\begin{array}{l}\text { Saya selalu merevisi } \\
\text { target anggaran } \\
\text { yang ditetapkan } \\
\text { setelah berjalan } 6 \\
\text { bulan. }\end{array}$ & 38 & 21,6 & $\begin{array}{c}10 \\
9\end{array}$ & 61,9 & 16 & 9,1 & 9 & 5,1 & 4 & 2,3 & 360 & 72 \\
\hline Rata-rata & $\begin{array}{c}19 \\
6\end{array}$ & $\begin{array}{c}11,1 \\
8\end{array}$ & $\begin{array}{l}47 \\
83\end{array}$ & 17,9 & 37,6 & $\begin{array}{c}21,4 \\
1\end{array}$ & 80,6 & 25,36 & $\begin{array}{c}26,1 \\
6\end{array}$ & $\begin{array}{l}14, \\
88\end{array}$ & $\begin{array}{c}671, \\
83\end{array}$ & $\begin{array}{c}107 \\
7\end{array}$ \\
\hline
\end{tabular}

Sumber : Data Primer yang Diolah (2020) 
Berdasarkan tabel diatas, bisa disimpulkan bahwa pernyataan atau indikator Biasanya target yang ditetapkan mudah dicapai berada pada range keempat yaitu tinggi dengan skor 620. Pernyataan atau indikator Kinerja Saya baik pada umumnya dinilai baik jika anggaran yang ditetapkan dapat dicapai dan dilaksanakan, berada pada range kedua yaitu rendah dengan skor 382 . Pernyataan atau indikator Kinerja Saya baik pada umumnya di nilai baik jika anggaran yang ditetapkan dapat di pertanggung jawabkan, berada pada range kelima yaitu sangat tinggi dengan skor 854. Pernyataan atau indikator Untuk mengetahui perkembangan kinerja yang baik pada umumnya baik jika rencana dan realisasi anggaran dari tahun ke tahun dapat diperbandingkan, berada pada range ketigaa yaitu cukup tinggi dengan skor 538. Pernyataan atau indikator Saya berperan dalam penentuan tujuan, kebijakan, rencana kegiatan seperti penjadwalan kerja, penyusunan anggaran dan penyusunan program, berada pada range keempat yaitu tinggi dengan skor 677. Dan pernyataan atau indikator Saya selalu merevisi target anggaran yang ditetapkan setelah berjalan 6 bulan. berada pada range kedua yaitu rendah dengan skor 360 .

b. Hasil Uji Kualitas Data

1) Uji Validitas

Pengujian ini dilakukan dengan cara menggunakan Corrected Item Total Corellation yaitu dengan cara mengkorelasi skor tiap item dengan skor totalnya, dengan jumlah responden 176 dan tingkat signifikasi 5\%, butir pertanyaan kuesioner dinyatakan valid jika $r_{\text {hitung }}>r_{\text {tabel }}$ dan sebaliknya. Dari penelitian ini diketahui bahwa $r_{\text {tabel }}$ sebesar 0,148 (DF : $176-2=174$ ). Hasil pengujian validitas variabel dependen dan independen dari 176 sampel responden tersebut dapat dilihat pada tabel 15.

Tabel 15 .Hasil Pengujian Validitas Data

\begin{tabular}{|l|c|c|c|}
\hline \multicolumn{1}{|c|}{ Variabel } & Item & Nilai r & Keterangan \\
\hline \multirow{4}{*}{$\begin{array}{l}\text { I. Partisipasi Penyusunan } \\
\text { Anggaran (X1) }\end{array}$} & $\mathrm{X} 1.1$ & 0.488 & Valid \\
\cline { 2 - 4 } & $\mathrm{X} 1.2$ & 0.412 & Valid \\
\cline { 2 - 4 } & $\mathrm{X} 1.3$ & 0.562 & Valid \\
\cline { 2 - 4 } & $\mathrm{X} 1.4$ & 0.517 & Valid \\
\cline { 2 - 4 } & $\mathrm{X} 1.5$ & 0.414 & Valid \\
\cline { 2 - 4 } & $\mathrm{X} 1.6$ & 0,546 & Valid \\
\hline II. Job Relevant Information (X2) & $\mathrm{X} 2.1$ & 0.470 & Valid \\
\cline { 2 - 4 } & $\mathrm{X} 2.2$ & 0.413 & Valid \\
\cline { 2 - 4 } & $\mathrm{X} 2.3$ & 0.618 & Valid \\
\cline { 2 - 4 } & $\mathrm{X} 2.4$ & 0.502 & Valid \\
\cline { 2 - 4 } & $\mathrm{X} 2.5$ & 0.465 & Valid \\
\hline IV. Kinerja Manajerial(Y) & $\mathrm{Y} .1$ & 0.544 & Valid \\
\cline { 2 - 4 } & $\mathrm{Y} .2$ & 0.532 & Valid \\
\cline { 2 - 4 } & $\mathrm{Y} .3$ & 0.605 & Valid \\
\cline { 2 - 4 } & $\mathrm{Y} .4$ & 0.486 & Valid \\
\cline { 2 - 4 } & $\mathrm{Y} .5$ & 0.344 & Valid \\
\cline { 2 - 4 } & $\mathrm{Y} .6$ & 0.405 & Valid \\
\hline
\end{tabular}

Sumber : Data Primer yang Diolah SPSS (2020) 
Invoice: Jurnal Ilmu Akuntansi

p-ISSN: 2714-6359 e-ISSN: 2714-6340

Vol.2 Nomor 2 September 2020

Berdasarkan tabel tersebut menunjukkan bahwa seluruh variabel tersebut valid karena nilai $r_{\text {hitung }}>r_{\text {tabel }}$ sehingga kuesioner pada penelitian dikatakan valid.

2) Uji Reliabilitas

Uji Reliabilitas dilakukan untuk menunjukan seja uh mana alat pengukuran dapat dipercaya. Secara umum suatu variabel dikatakan reliabilitas jika memberikan nilai cronbach alpha> 0,6 maka kuesioner penelitian tersebut dinyatakan reliable. Hasil pengujian reliabilitas dapat dilihat pada tabel 16.

Tabel 16. Hasil Pengujian Reliabilitas Data

\begin{tabular}{|l|c|c|}
\hline \multicolumn{1}{|c|}{ Variabel } & Koefisien Cronbach & Ket \\
\hline Partisipasi Penyusunan Anggaran (X1) & $\mathbf{7 , 1 5 8}$ & Reliabel \\
Job Relevant Information (X2) & $\mathbf{8 , 2 6 8}$ & Reliabel \\
Kinerja Manajerial (Y) & $\mathbf{7 , 2 1 6}$ & Reliabel \\
\hline
\end{tabular}

Sumber : Data Primer yang Diolah SPSS (2020)

Hasil uji reliabilitas berdasarkan tabel menunjukan bahwa seluruh variabel Partisipasi Penyusunan Anggaran (X1), Job Relevant Information (X2) dan Kinerja Manajerial(Y) mempunyai nilai koefisien cronbach alpha lebih besar dari 0,8. Dengan demikian seluruh variabel penelitian tersebut dinyatakan reliable dan selanjutnya dapat digunakan dalam penelitian ini.

3) Uji Asumsi Klasik

a) Uji Normalitas

Uji normalitas data dilakukan terdistribusi secara normal atau tidak yaitu dengan melihat Normal Probability Plot. Uji normalitas data dilakukan dengan menggunakan histogram standardizet residual dan PP plot standardizet residual. Uji normalitas bertujuan untuk menguji variabel dependen dan independen yaitu partisipasi penyusunan anggaran (X1) dan Job relevant Information (X2) terhadap Kinerja Manajerial (Y), keduanya memiliki distribusi normal atau tidak. Uji normalitas dapat dilihat pada gambar 2 .

untuk melihat bahwa suatu data

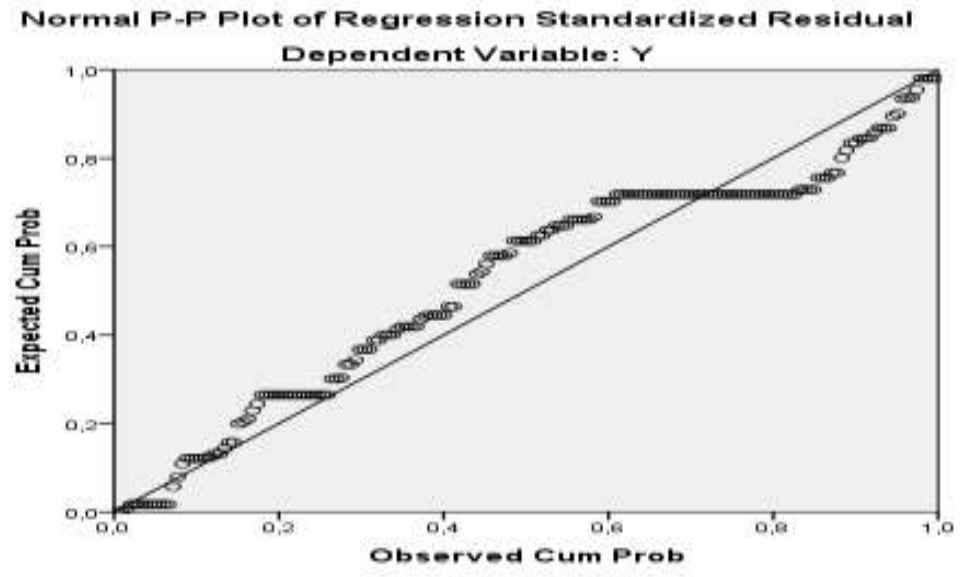

Sumber : Data Primer yang Diolah SPSS (2020) 
Pada grafik normal plot pada gambar 2 terlihat titik-titik yang menyebar di sekitar garis diagonal, serta penyebarannya mengikuti arah garis diagonal. Berdasarkan hal tersebut disimpulkan bahwa data terdistribusi normal.

b) Uji Mulitikolonieritas

Uji multikolonieritas bertujuan untuk menguji apakah dalam model regresi deitemukan adanya korelasi antara variabel bebas (independen). Jika variabel independen saling berkorelasi, maka variabel-variabel tidak ortogonal. Model regresi yang baik adalah yang bebas dari multikolonieritas. Nilai cut off yang umum dipakai untuk menunjukkan adanya multikolonieritas adalah nilai tolerance $>0,10$ atau sama dengan nilai VIF $<10$. Berdasarkan hasil pengolahan data Variance Inflation Factor (VIF) pada tabel menunjukkan bahwa nilai VIF $<10$ sehingga dikategorikan bebas dari multikolonieritas artinya variabelvariabel independen ortogonal.

Tabel 17. Hasil Uji Multikolonieritas

\section{Coefficients $^{\text {a }}$}

\begin{tabular}{|c|c|c|c|c|c|}
\hline \multirow[b]{2}{*}{ Model } & \multicolumn{2}{|c|}{$\begin{array}{l}\text { Unstandardized } \\
\text { Coefficients }\end{array}$} & \multirow{2}{*}{$\begin{array}{c}\text { Standardized } \\
\text { Coefficients } \\
\text { Beta }\end{array}$} & \multirow[b]{2}{*}{$\mathrm{T}$} & \multirow[b]{2}{*}{ Sig. } \\
\hline & B & Std. Error & & & \\
\hline 1 (Constant) & 2,024 & ,293 & & 6,909 & ,000 \\
\hline $\mathrm{X} 1$ & ,200 & ,090 & ,202 & 2,225 & ,027 \\
\hline $\mathrm{X} 2$ & ,352 & ,082 & ,393 & 4,318 & ,000 \\
\hline
\end{tabular}

a. Dependent Variable: Y

Sumber Data Primer 2020

Berdasarkan tabel di atas menunjukkan semua variabel bebas mempunyai nilai Tolerance $>0,10$ dan nilai VIF $<10$, dengan demikian, dapat disimpulkan bahwa kedua variabel bebas dalam penelitian ini, tidak terjadi multikolinieritas.

c) Uji Heteroskedastisitas

Uji heteroskedasitisitas bertujuan untuk menguji apakah dalam model regresi terjadi ketidaksamaan variance dari residual satu pengamatan ke satu pengamatan yang lain. Jika variance dari residual satu pengamatan ke pengamatan yang lain tetap, maka disebut homoskedastisitas dan jika berbeda disebut heteroskedastisitas. Model regresi yang baik adalah yang homoskedastisitas atau jika tidak terjadi heteroskedastisitas. Berdasarkan hasil pengolahan data, maka hasil scatterplot dapat dilihat pada gambar 3 .

Gambar 3. Hasil Uji Heterokedastisitas

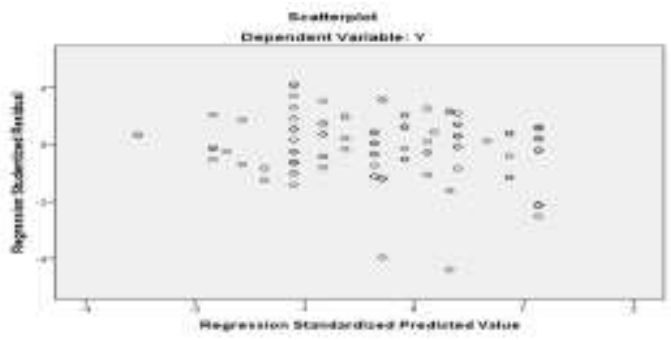

Sumber : Data Primer yang Diolah SPSS (2020)

4) Pengujian Hipotesis

Koefisien Kontingensi adalah uji korelasi antara dua variabel yang berskala data nominal. Fungsinya adalah untuk mengetahui asosiasi atau relasi antara dua perangkat atribut. Koefisien ini fungsinya sama dengan beberapa jenis koefisien korelasi lainnya, seperti koefisien korelasi phi, cramer, lambda, uncertainty, spearman, kendall tau, gamma, Sommer's. Namun dalam hal ini, Kontingensi $\mathrm{C}$ adalah uji korelasi 
yang spesifik untuk data berskala nominal. Selain itu uji ini juga paling sering atau lazim digunakan dibandingkan uji koefisien korelasi data nominal lainnya.

a) Uji Koefisien Determinasi $\left(\mathrm{R}^{2}\right)$

Tabel 19. Koefisien Determinasi (R Square)

Model Summaryb

\begin{tabular}{|l|r|r|r|r|}
\hline Model & \multicolumn{1}{|c|}{$\mathrm{R}$} & R Square & $\begin{array}{c}\text { Adjusted R } \\
\text { Square }\end{array}$ & $\begin{array}{c}\text { Std. Error of } \\
\text { the Estimate }\end{array}$ \\
\hline 1 &, $557 \mathrm{a}$ &, 310 &, 302 &, 37126 \\
\hline
\end{tabular}

a. Predictors: (Constant), X1

b. Dependent Variable: Y

Berdasarkan tabel regresi linear berganda (Model Summary) diperoleh nilai koefisien determinasi $\mathrm{R}^{2}$ sebesar 0.310 atau $31 \%$ menunjukan bahwa 2 variabel independen (Partisipasi penyusunan anggaran dan Job relevant Information) secara simultan berpengaruh terhadap variabel dependen (Kinerja Manajerial).

b) Uji Signifikan Parsial (Uji Statistik F)

Tabel 19 Uji Signifikan Parsial

\begin{tabular}{llr|r|r|r|r} 
& Sum of Squares & df & Mean Square & \multicolumn{1}{c}{ F } & \multicolumn{1}{c}{ Sig. } \\
\hline 1 & Regression & 10,698 & 2 & 5,349 & 38,807 &, $000^{\text {b }}$ \\
\cline { 2 - 8 } & Residual & 23,846 & 173 &, 138 & & \\
\cline { 2 - 8 } & Total & 34,544 & 175 & & & \\
\hline
\end{tabular}

a. Dependent Variable: $Y$

b. Predictors: (Constant), X2, X1

Berdasarkan perhitungan dengan menggunakan uji $\mathrm{F}$ diperoleh nilai $\mathrm{F}_{\text {hitung }}$ 38,807 dengan tingkat signifikan karena probabilitas signifikansi jauh lebih kecil dari 0,05 maka model regresi dapat digunakan memprediksi variabel Kinerja Manajerial(Y) atau dapat dikatakan bahwa partisipasi penyusunan anggaran $\left(\mathrm{X}_{1}\right)$, job relevant information $\left(\mathrm{X}_{2}\right)$ berpengaruh terhadap Kinerja Manajerial (Y). hal ini menandakan $\mathrm{H}_{\mathrm{a}}$ diterima dan $\mathrm{H}_{0}$ ditolak.

c) Uji Signifikan Parameter Individual (Uji t )

Uji t menunjukan seberapa jauh pengaruh satu variabel independen secara individual mampu memerankan variasi variabel dependen. Jika nilai $t_{\text {hitung }}$ $>t_{\text {tabel }}$ maka variabel independen secara individu berpengaruh terhadap variabel dependen. Tingkat signifikan yang digunakan adalah 0.05. diketahui $t_{\text {tabel }}(\mathrm{df}$ : n-k-1 atau 176-2-1 = 173). Berdasarkan hasil uji t diperoleh data sebagaimana dirangkum pada tabel 15 . 
Tabel 20. Rangkuman Hasil Pengujian Uji Statistik t

Coefficients ${ }^{a}$

\begin{tabular}{|c|c|c|c|c|c|c|c|c|}
\hline \multirow{2}{*}{\multicolumn{2}{|c|}{ Model }} & \multicolumn{2}{|c|}{$\begin{array}{c}\text { Unstandardized } \\
\text { Coefficients }\end{array}$} & \multirow{2}{*}{\begin{tabular}{|c}
$\begin{array}{c}\text { Standardize } \\
\mathrm{d}\end{array}$ \\
Coefficients \\
Beta \\
\end{tabular}} & \multirow[b]{2}{*}{$\mathrm{T}$} & \multirow[b]{2}{*}{ Sig. } & \multicolumn{2}{|c|}{$\begin{array}{c}\text { Collinearity } \\
\text { Statistics }\end{array}$} \\
\hline & & B & $\begin{array}{l}\text { Std. } \\
\text { Error }\end{array}$ & & & & $\begin{array}{c}\text { Toleranc } \\
\text { e }\end{array}$ & VIF \\
\hline & (Constant) & 2,024 & ,293 & & 6,909 & ,000 & & \\
\hline & $\mathrm{X} 1$ & 200, & ,090 & 202 & 2,225 & ,027 & ,482 & $\begin{array}{r}2,07 \\
4\end{array}$ \\
\hline
\end{tabular}

a. Dependent Variable: $Y$

Sumber : Data Primer yang Diolah SPSS (2020)

Berdasarkan tabel 21 dapat dilihat bahwa variabel partisipasi anggaran memiliki t hitung sebesar 2,225 dengan tingkat signifikansi sama dengan 0,27 yang lebih kecil dari 0,05, maka Ho ditolak dan $\mathrm{Ha}$ diterima. Ini berarti partisipasi anggaran berpengaruh signifikan terhadap kinerja manajerial. Dengan demikian hipotesis pertama yang menyatakan partisipasi anggaran berpengaruh terhadap kinerja manajerial pemerintah daerah kabupaten Pinrang terbukti. Hasil penelitian ini menujukkan bahwa Semakin tinggi partisipasi anggaran maka kinerja manajerial aparat pemerintah daerah kabupaten Pinrang juga akan semakin meningkat.

5) Hasil Uji variabel Moderating

\section{Variabel Moderating: adalah} variabel yang mempengaruhi (memperkuat dan memperlemah) hubungan antara variabel independen dengan dependen. Variabel disebut juga sebagai variabel independen ke dua. $\mathrm{H} 2$ : Job relevant information berpengaruh terhadap hubungan partisipasi anggaran terhadap kinerja manajerial pemerintah daerah.

Persamaan regresi menggambarkan apakah variabel job relevant information merupakan variabel moderasi, ditunjukkan dengan nilai koefisien b2 kinerja manajerial pemerintah daerah. Apabila nilai koefisien b2 kinerja manajerial pemerintah daerah hasilnya negatif dan signifikan, maka dapat disimpulkan bahwa variabel job relevant information merupakan variabel moderasi yang memoderasi pengaruh partisipasi anggaran terhadap kinerja manajerial pemerintah daerah, sebaliknya jika koefisien b2 kinerja manajerial pemerintah daerah hasilnya positif dan tidak signifikan, maka variabel job relevant information bukan merupakan variabel moderasi.

Selanjutnya tabel hasil uji residual persamaan regresi (2) adalah sebagai berikut:

Tabel 21. Hasil Uji Residual Persamaan Regresi ( Uji Moderasi ) Model Summaryb

\begin{tabular}{|l|r|r|r|r|}
\hline Model & $\mathrm{R}$ & \multicolumn{1}{|c|}{ R Square } & Adjusted R Square & $\begin{array}{c}\text { Std. Error of the } \\
\text { Estimate }\end{array}$ \\
\hline 1 &, $557^{\mathrm{a}}$ &, 310 &, 302 &, 37126 \\
\hline
\end{tabular}

a. Predictors: (Constant), Moderat, X2 
b. Dependent Variable: $\mathrm{Y}$

ANOVA $^{a}$

\begin{tabular}{|c|c|c|c|c|c|c|}
\hline \multicolumn{2}{|c|}{ Model } & $\begin{array}{c}\text { Sum of } \\
\text { Squares }\end{array}$ & Df & Mean Square & $\mathrm{F}$ & Sig. \\
\hline \multirow[t]{3}{*}{1} & Regression & 10,698 & 2 & \multirow{3}{*}{$\begin{array}{r}5,349 \\
138\end{array}$} & \multirow[t]{3}{*}{38,807} & \multirow[t]{3}{*}{, $000^{\mathrm{b}}$} \\
\hline & Residual & 23,846 & 173 & & & \\
\hline & Total & 34,544 & 175 & & & \\
\hline
\end{tabular}

a. Dependent Variable: $Y$

b. Predictors: (Constant), Moderat, X2

\section{Coefficients $^{\mathrm{a}}$}

\begin{tabular}{|c|c|c|c|c|c|c|c|c|}
\hline \multirow{2}{*}{\multicolumn{2}{|c|}{ Model }} & \multicolumn{2}{|c|}{$\begin{array}{c}\text { Unstandardized } \\
\text { Coefficients }\end{array}$} & \multirow{2}{*}{$\begin{array}{c}\begin{array}{c}\text { Standardize } \\
\text { d } \\
\text { Coefficients }\end{array} \\
\text { Beta }\end{array}$} & \multirow[b]{2}{*}{$\mathrm{T}$} & \multirow[b]{2}{*}{ Sig. } & \multicolumn{2}{|c|}{$\begin{array}{c}\text { Collinearity } \\
\text { Statistics }\end{array}$} \\
\hline & & B & $\begin{array}{l}\text { Std. } \\
\text { Error }\end{array}$ & & & & $\begin{array}{c}\text { Toleranc } \\
\mathrm{e}\end{array}$ & VIF \\
\hline \multirow[t]{3}{*}{1} & (Constant) & 2,024 & 293 & & 6,909 & ,000 & & \\
\hline & $\mathrm{X} 1$ & 200 & 090 & 202 & 2,225 & ,027 & 482 & 2,074 \\
\hline & $\mathrm{X} 2$ & 352 & ,082 & 393 & 4,318 & ,000 & ,482 & 2,074 \\
\hline
\end{tabular}

a. Dependent Variable: $Y$

Berdasarkan hasil uji statistik regresi (uji residual) yang dilakukan, diketahui bahwa komitmen organisasi memiliki nilai parameter positif dan memiliki nilai signifikan senilai 2,074. Sebuah variabel dikatakan variabel moderasi jika memiliki koefisien yang positif dan berpengaruh signifikan pada tingkat 0,05 , sehingga dapat disimpulkan bahwa variabel job relevant information merupakan variabel moderasi yang memperkuat atau mempengaruhi hubungan variabel partisipasi anggaran terhadap kinerja manajerial pemerintah daerah Kabupaten Pinrang.

$$
\text { Job relevant information }
$$
merupakan variabel moderasi berarti membuktikan dan menerima hipotesis kedua (H2) dimana interaksi antara job relevant information dan partisipasi anggaran akan berpengaruh terhadap peningkatan kinerja manajerial pemerintah daerah Kabupaten Pinrang

\subsection{Pembahasan}

Berdasarkan hasil penelitian yang menguji pengaruh partisipasi penyusunan anggarandan job relevant information di Kantor OPD Kabupaten Pinrang yang telah diuraikan di atas, maka ada beberapa hal yang dapat dijelaskan dalam penelitian ini yaitu :

\section{Pengaruh Partisipasi Penyusunan \\ Anggaran terhadap Kinerja Manajerial}

Uji hipotesis menunjukkan angka signifikansi sebesar 0,000 di bawah 0,05, sehingga $\mathrm{H} 1$ diterima atau dengan kata lain hipotesis pertama yang menyatakan bahwa Partisipasi Penyusunan Anggaran berpengaruh terhadap Kinerja Manajerial. Hal tersebut dapat dilihat dari persamaan regresi sebagai berikut:

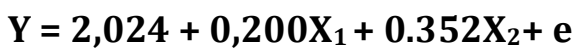

Berdasarkan persamaan di atas dapat dilihat nilai koefisiensi Partisipasi Penyusunan Anggaran adalah positif yang berarti bahwa Partisipasi. 
Penyusunan Anggaran berpengaruh positif terhadap Kinerja Manajerial. Jika Partisipasi Penyusunan Anggaran semakin tinggi, maka Kinerja Manajerial akan meningkat. Hasil penelitian ini mendukung hasil penelitian yang dilakukan oleh muh Basri L (2017) dengan judul "Analisis Pengaruh Partisipasi Penyusunan Anggaran Terhadap Kinerja Manajerial Job Relevant Information sebagai Variabel Moderating." Hasil dari penelitian tersebut menunjukkan Partisipasi Penyusunan Anggaran berpengaruh terhadap Kinerja Manajerial.

Hasil penelitian ini
mengindikasikan bahwa terdapat pengaruh positif Partisipasi Penyusunan Anggaran terhadap Kinerja Manajerial. Semakin tinggi keterlibatan manajer dalam Partisipasi Penyusunan Anggaran maka akan meningkatkan Kinerja Manajerial. Partisipasi penyusunan anggaran merupakan keterlibatan para manajer dalam suatu organisasi dalam pencapaian sasaran yang telah ditetapkan dalam anggaran. Dengan adanya partisipasi tersebut akan mendorong para manajer untuk bertanggung jawab terhadap masingmasing tugas yang diembannya sehingga para manajer akan meningkatkan kinerja agar mereka dapat mencapai sasaran atau target yang telah ditetapkan dalam anggaran. Hal ini mengindikasikan adanya hubungan yang positif antara Partisipasi Penyusunan Anggaran dengan Kinerja Manajerial. Jadi keterlibatan manajer dalam penyusunan anggaran dapat berpengaruh positif dengan meningkatnya Kinerja Manajerial.

Partisipasi Penyusunan Anggaran mempunyai peran yang cukup besar dan mempunyai pengaruh yang kuat terhadap Kinerja Manajerial. Berdasarkan data yang diperoleh, skor jawaban responden pada Partisipasi Penyusunan Anggaran paling tinggi dalam hal pengaruh responden tercermin dalam anggaran final/akhir. Hal tersebut mengindikasikan adanya partisipasi aktif yang dikarenakan organisasi pemerintah dalam hal ini OPD Kabupaten Pinrang sungguh-sungguh dalam menerapkan partisipasi. Manajer tingkat bawah menyatakan mengambil andil dalam persetujuan terhadap setiap keputusan yang ditetapkan oleh manajemen puncak karena perusahaan memerlukan persetujuan mereka.

Berdasarkan teori diatas, tujuan dari penelitian ini adalah bagaimana meningkatkan kinerja manajerial sesuai dengan visi dan misi organisasi, Seperti yang diungkapkan oleh Kusuma, (Latham, et al, 2013:10) menemukan bahwa teori goal-setting dalam penetapan tujuan organisasi berpengaruh pada kinerja pegawai dalam organisasi publik dalam mencapai tujuan. Salah satu bentuk nyata dari penerapan goal-setting ini adalah anggaran. Sebuah anggaran tidak hanya mengandung rencana dan jumlah nominal yang dibutuhkan untuk melakukan kegiatan, tetapi juga mengandung sasaran yang spesifik yang ingin dicapai organisasi.

Berdasarkan penelitian-penelitian yang telah dilakukan, temuan utama dari goal-setting theory adalah bahwa orang yang diberi tujuan yang spesifik, sulit tapi dapat dicapai, memiliki kinerja yang lebih baik dibandingkan orang-orang yang menerima tujuan yang mudah dan spesifik atau tidak ada tujuan sama sekali. Pada saat yang sama, seseorang juga harus memiliki kemampuan yang cukup, menerima tujuan yang ditetapkan dan menerima umpan balik yang berkaitan dengan kinerja.
2. Job Relevant Information memperkuat pengaruh Partisipasi Penyusunan Anggaran terhadap Kinerja Manajerial. 
Berdasarkan kriteria jenis variabel moderating, Job relevant Information dalam penelitian ini sebagai variabel moderator. Job Relevant Information terbukti memoderasi hubungan antara Partisipasi Penyusunan Anggaran dengan Kinerja Manajerial. Job Relevant Information meningkatkan kinerja melalui pemberian perkiraan yang lebih akurat mengenai lingkungan sehingga dapat dipilih rangkaian tindakan efektif yang terbaik. informasi yang membantu manajer untuk meningkatkan kinerjanya dengan informasi lebih baik. Job relevant information menjadi jenis informasi yang sangat penting bagi manajer untuk meningkatkan kinerjanya.

Banyaknya Job Relevant Information yang diberikan kepada manajemen membuat Job Relevant Information mampu memoderasi keterlibatan individu atau aparat pemerintah terkait keikutsertakannya dalam penyusunan anggaran yang akan mampu mendorong pegawai atau aparat pemerintah tersebut untuk dapat bertanggung jawab terhadap tugas yang di kerjakannya sehingga dapat meningkatkan kinerjanya.

\section{PENUTUP}

\subsection{Simpulan}

Penelitian ini bertujuan untuk menguji secara empiris pengaruh partisipasi anggaran terhadap kinerja manajerial dengan komitmen organisasi dan job relevant information sebagai variabel moderating dapat diambil kesimpulan bahwa:

1. Partisipasi anggaran berpengaruh positif dan signifikan terhadap kinerjamanajerial pemerintah daerah Kabupaten Pinrang.

2. Variabel Job Relevant Informationt sebagai variabel moderating mempengaruhi kuat hubungan partisipasi anggaran terhadap kinerja manajerial

\subsection{Saran}

Berdasarkan hasil penelitian yang telah diuraikan dalam pembahasan dan keterbatasan yang ada dalam penelitian ini, terdapat beberapa saran yang diharapkan dapat menjadi bahan pertimbangan untuk peneliti selanjutnya dan objek penelitian yaitu :

1. Bagimanajer tingkat atas atau Kepala bidang/bagian untuk mempertimbangkan masukan anggaran dari manajer tingkat menengah dan bawah, sehingga diharapkan kinerja manajer dapat meningkat terutama pada saat musrembang kecamatan.

2. Bagi para manajer lebih meningkatkan kemampuan negosiasi mereka dalam melakukan kontrak dengan pihak luar. Kegiatan tersebut akan efektif dan efisien karena kebutuhan pada tiap-tiap bagian adalah manajer bagian masingmasing.

3. Bagi para manajer diharapkan lebih meningkatkan lagi koordinasi dengan para manajer di bidang lain, sehingga informasi yang berkaitan dengan tugas mampu membantu manajer dalam pengambilan keputusan saat penyusunan anggaran.

4. Bagi peneliti atau calon peneliti yang lain agar menambah jumlah populasi dan sampel, misalnya memperluas penelitian tidak hanya di dinas pemerintah kota namun juga penelitian di dinas pemerintah provinsi maupun dinas pemerintah daerah pada daerah lain sehingga data yang didapat lebih luas dan dapat membandingkan antara dinas satu 
dengan dinas yang lain dan menambahkan indikator penelitian dalam mengukur pengaruh partisipasi penyusunan anggaran terhadap kinerja manajerial. Dan untuk OPD Kabupaten Pinrang diharapkan memegang teguh kode etik kepegawaian sebagai pekerja Negara agar penyusunan anggaran mampu lebih maksimal.

\section{DAFTAR PUSTAKA}

Arifah. (2014). Manajemen Keuangan Sektor Publik Problematika Penerimaan dan Pengeluaran Pemerintah (Anggaran Pendapatan dan Belanja Negara/Daerah). Jakarta. Salemba Empat.

Arfan Ikhsan Lubis . (2011). Akuntansi Keperilakuan Edisi 2.Jakarta. Salemba Empat

Arfan Ikhsan dan Muhammad Ishak. (2008).Akuntansi

Keperilakuan.Jakarta. Salemba Empat.

BambangSardjito dan Osmad Muthaher (2007).“Pengaruh Partisipasi Penyusunan Anggaran Terhadap Kinerja Aparat Pemerintah Daerah: Budaya Organisasi Dan Komitmen Organisasi sebagai Variabel Moderating."

Brownell, Peter. (1980). "Participation in Budgeting, Locus of Control, and Organizational Effectiveness". Dissertation. Alfred P. Sloan School of Management. Cambridge.

Brownell, P., \& Morris Mc Innes. (1986). "Budgetary Participation, Motivation, and Performance". The Accounting Review, Vol.61, No.4, October 1986 page 587-600.

Brownell, P., \& Mark Hirst. (1986). "Reliance on Accounting Information, Budgetary Participation, and Task
Uncertainty: Tests of A Three Way Interaction". The Accounting Review, Vol.24, No.2, 1986.

Daft, Richard L. 2006. Manajemen Edisi keenam. Jakarta: Salemba Empat.

Damodar N. Gujarati. 2003. Basic Econometrics. Jakarta: Erlangga.

Deddi Noerdiawan. 2006. Akuntansi Sektor Publik. Jakarta : Salemba Empat

Eker, Melek. (2008). “The Impact of Budget Participation on Managerial Performance Via Organizational Commitmen: A Study on The Top 500 Firm in Turkey". Ankara Üniversitesi SBF Dergisi 64-4.

Eka Yudha Utama. (2013). "Pengaruh Partisipasi Penyusunan Anggaran Terhadap Kinerja Manajerial: Komitmen Organisasi Dan Persepsi Inovasi Sebagai Variabel Intervening (Studi Empiris Pada Satuan Kerja Instansi Vertikal Wilayah Pembayaran Kantor Pelayanan Perbendaharaan Negara Sampit)." Tesis. Universitas Diponegoro.

Febri Hendri. (2008). "Pengaruh Partisipasi Anggaran TerhadapSenjangan Anggaran Dengan KomitmenOrganisasi Sebagai Variabel Moderating(Studi Empiris Pada Pemerintahan Daerah Kabupaten Sleman Di Yogyakarta)." Tesis. Universitas Islam Indonesia.

Gitosudarmo dan Sudita (1997) "Work and Notivation". Jakarta

Hansen, Don R.dan Marryane M. Mowen. 2004. Akuntansi Manajemen, Edisi tujuh. Jakarta: Salemba Empat.

Harun. (2009). Reformasi Akuntansi dan Manajemen Sektor Publik di Indonesia. Jakarta. Salemba Empat

http://perilakuorganisasi.com/teoriharapan.html 
http://perilakuorganisasi.com/teoripenetapan-tujuan.html

Indra Bastian.(2006).Akuntansi Sektor Publik: Suatu Pengantar. Jakarta.Erlangga.

Indra Bastian. (2009).Akuntansi Sektor Publik di Indonesia. Yogyakarta. BPFE

Kren, Leslie. (1992) "Budgetary Participation and Managerial Performance: The Impact of Information and Environmental Volatility" The Accounting Review Vol. 67 No. 3

Krisler Bornadi Ompusunggu dan Icuk Rangga Bawono. (2006). "Pengaruh Partisipasi Anggaran Dan Job Relevant Information (JRI) Terhadap Informasi Asimetris (Studi pada Badan Layanan Umum Universitas Negeri di Kota Purwokerto Jawa Tengah)." Jurnal Simposium Nasional 9 Padang

Kunwaviyah Nurcahyani. (2010). "Pengaruh Partisipasi AnggaranTerhadap Kinerja ManajerialMelalui Komitmen Organisasi DanPersepsi Inovasi Sebagai VariabelIntervening." Tesis.Universitas Diponegoro.

Kurnia, Ratnawati. 2010. "Pengaruh Budgetary Goal Characteristics terhadap Kinerja Managerial dengan Budaya Paternalistik dan Komitmen Organisasi sebagai Moderating Variabel." Ultima Accounting, Vol. 2, No.2.

Kusnasriyanti Yusfaningrum dan Imam Ghozali. (2006). "Analisis Pengaruh Partisipasi Anggaran Terhadap Kinerja Manajerial Melalui Komitmen Tujuan Anggaran Dan Job Relevant Information (JRI) Sebagai Variabel Intervening (Penelitian Terhadap Perusahaan Manufaktur Di Indonesia)."
Malayu S.P.Hasibuan. (2007). MANAJEMEN: Dasar, Pengertian, dan Masalah. Jakarta. Bumiaksara

Milani, Ken. (1975). "The Relationship of Participation in Budget-Setting to Industrial Supervisor Performance and Attitudes: A Field Study". The Accounting Review. Vol. 50, No. 2 April 1975 page 274-284.

Mardiasmo. (2002). Akuntansi Sektor Publik. Yogyakarta : ANDI

Mulyadi dan Jhoni. 2001.

Sistem Perencanaan dan Pengendalian Manajemen. Yogyakarta: Aditya Media

Nanda Hapsari A.R. (2010). "Pengaruh Partisipasi Penyusunan Anggaran Terhadap Kinerja Manajerial Dengan Komitmen Organisasi Dan Locus Of Control Sebagai Variabel Moderating (Studi Kasus Pada PT Adhi Karya (Persero) Tbk. Divisi Kontruksi I)". Tesis. Universitas Diponegoro. Semarang.

Nor, W. 2007. "Desentralisasi dan Gaya Kepemimpinan Sebagai Variabel Moderating dalam Hubungan Antara Partisipasi Penyusunan Anggaran dan Kinerja". Simposium Nasional Akuntansi X, hal. 1-27

Purbayu Budi Santosa dan Ashari. 2005. Analisis Statistik dengan Microsoft Excel dan SPSS. Jakarta: ANDI

Rakib Husin, Made Sudarma, Rosidi. (2010). "Pengaruh Partisipasi Anggaran Terhadap Kinerja Pimpinan dengan Desentralisasi, Budget Goal Commitment dan Job Relevant Information Sebagai Variabel Moderating."

Ramadhani dan Nasution. 2009. "Pengaruh partisipasi anggaran terhadap prestasi manajer pusat pertanggungjawaban dengan motivasi sebagai variabel mediating". Jurnal tidak dipublikasikan. Faculty of 
Economic, University of Sumatra Utara.

Ridwan Mattola. (2011).“Pengaruh Partisipasi Anggaran Terhadap Kinerja Dengan Locus of Control Sebagai Variabel Moderating (Studi Kasus Pada Pt Kimia Farma Trading \& Distribution Cabang Makasar)" Tesis. Universitas Hasanuddin.

Siagian P. Sondang. 2002. Kiat Meningkatkan Produktivitas Kerja. Jakarta : Rineka Cipta

Sugiyono. (2010). Metode Penelitian Pendidikan. Bandung: Alfabeta. . (2009). Metode Penelitian Bisnis. Bandung: Alfabeta.

Sumadiyah dan Susanta, Sri. 2004. "Job Relevant Information dan Ketidakpastian Lingkungan dalam Hubungan Partisipasi Penyusunan Anggaran dan Kinerja Manajerial." Simposium Nasional Akuntansi VII Bali.

Syamsul. (2016). Determinan Implementasi Kebijakan Pengembangan Sumber Daya Aparatur Pemerintah Daerah Kabupaten Sidenreng Rappang, Tesis Universitas Negri Makassar, Makassar.

T. Hani Handoko. 1996. Manajemen Perencanaan dan Sumber Daya Manusia. Yogyakarta: PT BPFE

Winardi. (2000). Asas-asas Manajemen. Bandung: Mandar Maju.

Wirawan. (2009). Evaluasi Kinerja Sumber Daya Manusia. Jakarta: Salemba Empat.

Wiyono,Gendro. 2011. Merancang Penelitian Bisnis dengan alat analisis SPSS 17.0 \& Smart PLS 2.0. Edisi Pertama. Yogyakarta: YKPN.

Yogi Adrianto. (2008). "Analisis Pengaruh Partisipasi Penyusunan AnggaranTerhadap Kinerja
Manajerial Dengan KepuasanKerja, Job Relevant Information Dan KepuasanKerja Sebagai Variabel Moderating(Studi Empiris Pada Rumah Sakit Swasta Di Wilayah Kota Semarang)." Tesis. Universitas Diponegoro.

Yulia. (2013). "Pengaruh Partisipasi Penganggaran, Job Relevant Information (JRI) Dan Volatilitas Lingkungan Terhadap Kinerja Manajerial Pada Perusahaan Manufaktur" 